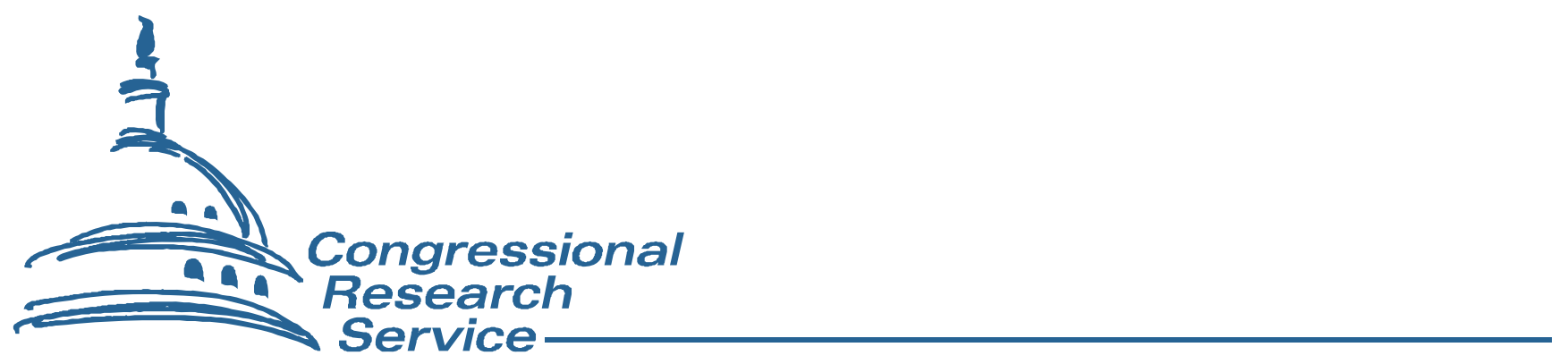

\title{
Tax Havens: International Tax Avoidance and Evasion
}

\section{Jane G. Gravelle}

Senior Specialist in Economic Policy

July 9, 2009

Congressional Research Service 


\section{Summary}

The federal government loses both individual and corporate income tax revenue from the shifting of profits and income into low-tax countries, often referred to as tax havens. The revenue losses from this tax avoidance and evasion are difficult to estimate, but some have suggested that the annual cost of offshore tax abuses may be around $\$ 100$ billion per year. International tax avoidance can arise from large multinational corporations who shift profits into low-tax foreign subsidiaries or wealthy individual investors who set up secret bank accounts in tax haven countries.

Recent actions by the Organization for Economic Cooperation and Development (OECD) and the G-20 industrialized nations have targeted tax haven countries, focusing primarily on evasion issues. There are also a number of legislative proposals that address these issues including the Stop Tax Haven Abuse Act (S. 506, H.R. 1265); draft proposals by the Senate Finance Committee; two other related bills, S. 386 and S. 569; and a proposal by President Obama.

Multinational firms can artificially shift profits from high-tax to low-tax jurisdictions using a variety of techniques, such as shifting debt to high-tax jurisdictions. Since tax on the income of foreign subsidiaries (except for certain passive income) is deferred until repatriated, this income can avoid current U.S. taxes and perhaps do so indefinitely. The taxation of passive income (called Subpart F income) has been reduced, perhaps significantly, through the use of "hybrid entities" that are treated differently in different jurisdictions. The use of hybrid entities was greatly expanding by a new regulation (termed "check-the-box") introduced in the late 1990s that had unintended consequences for foreign firms. In addition, earnings from income that is taxed can often be shielded by foreign tax credits on other income. On average very little tax is paid on the foreign source income of U.S. firms. Ample evidence of a significant amount of profit shifting exists, but the revenue cost estimates vary from about $\$ 10$ billion to $\$ 60$ billion per year.

Individuals can evade taxes on passive income, such as interest, dividends, and capital gains, by not reporting income earned abroad. In addition, since interest paid to foreign recipients is not taxed, individuals can also evade taxes on U.S. source income by setting up shell corporations and trusts in foreign haven countries to channel funds. There is no general third party reporting of income as is the case for ordinary passive income earned domestically; the IRS relies on qualified intermediaries (QIs)who certify nationality without revealing the beneficial owners. Estimates of the cost of individual evasion have ranged from $\$ 40$ billion to $\$ 70$ billion.

Most provisions to address profit shifting by multinational firms would involve changing the tax law: repealing or limiting deferral, limiting the ability of the foreign tax credit to offset income, addressing check-the-box, or even formula apportionment. President Obama's proposals include a proposal to disallow overall deductions and foreign tax credits for deferred income and restrictions on the use of hybrid entities. Provisions to address individual evasion include increased information reporting, and provisions to increase enforcement, such as shifting the burden of proof to the taxpayer, increased penalties, and increased resources. Individual tax evasion is the main target of the proposed Stop Tax Haven Abuse Act and the Senate Finance Committee proposals; some revisions are also included in President Obama's plan. 


\section{Contents}

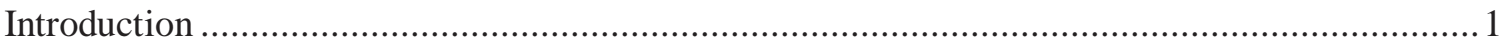

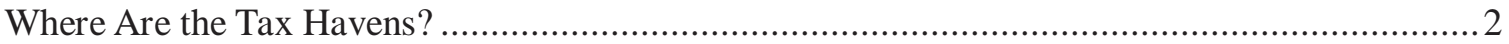

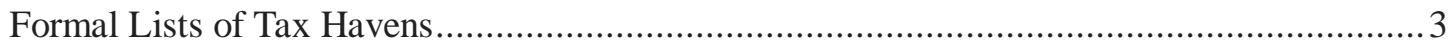

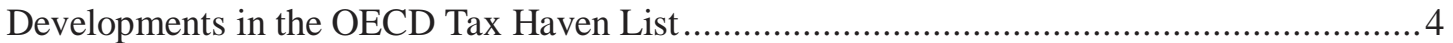

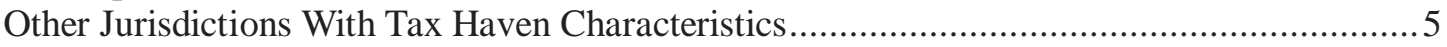

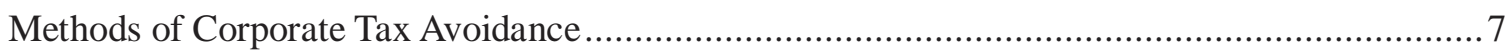

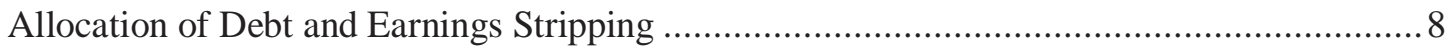

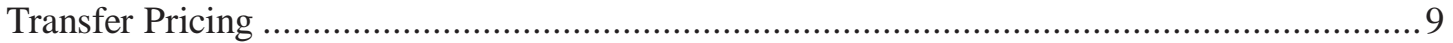

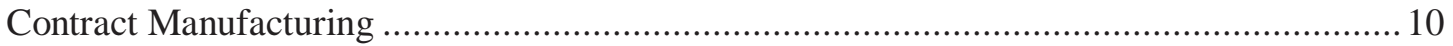

Check-the-Box, Hybrid Entities, and Hybrid Instruments ................................................. 10

Cross Crediting and Sourcing Rules for Foreign Tax Credits ............................................ 11

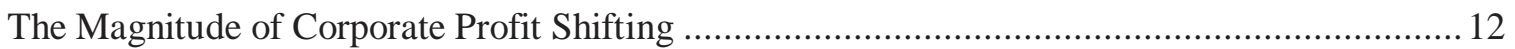

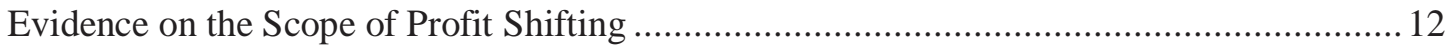

Estimates of the Cost and Sources of Corporate Tax Avoidance ........................................... 15

Importance of Different Profit Shifting Techniques.......................................................... 17

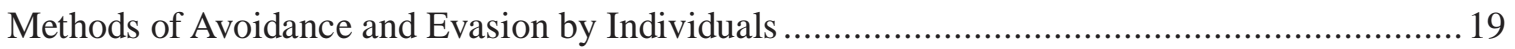

Tax Provisions Affecting the Treatment of Income by Individuals.................................... 19

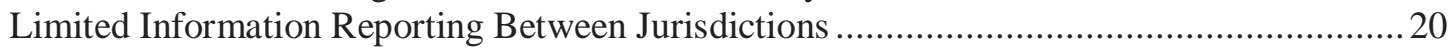

U.S. Collection of Information on U.S. Income and Qualified Intermediaries .....................20

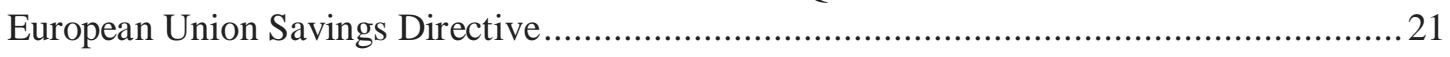

Estimates of the Revenue Cost of Individual Tax Evasion...................................................... 21

Alternative Policy Options to Address Corporate Profit Shifting .............................................22

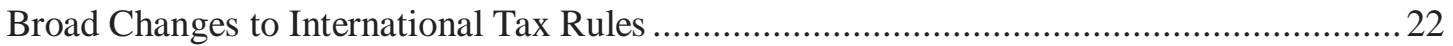

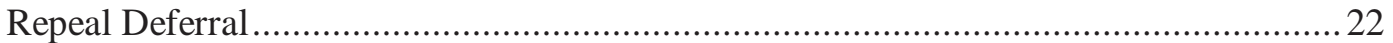

Targeted or Partial Elimination of Deferral .................................................................. 23

Allocation of Deductions and Credits with Respect to Deferred

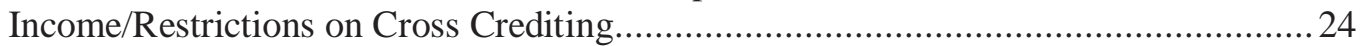

Formula Apportionment ....................................................................................... 24

Eliminate Check the Box, Hybrid Entities, and Hybrid Instruments; Foreign Tax

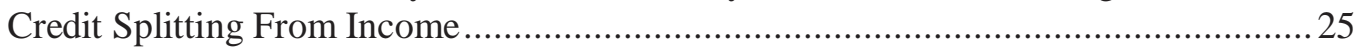

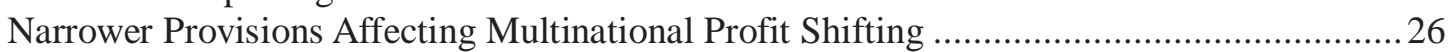

Tighten Earnings Stripping Rules ......................................................................... 26

Foreign Tax Credits: Source Royalties as Domestic Income for Purposes of the Foreign Tax Credit Limit, Or Create Separate Basket; Eliminate Title Passage Rule; Restrict Credits for Taxes Producing an Economic Benefit ..............................226

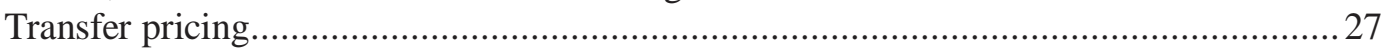

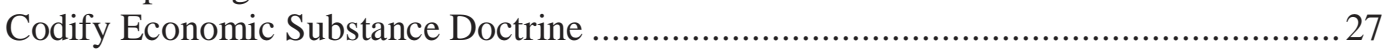

Prevent Dividend Repatriation Through Reorganizations.......................................... 27

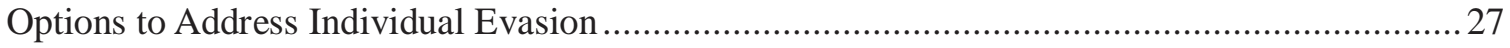

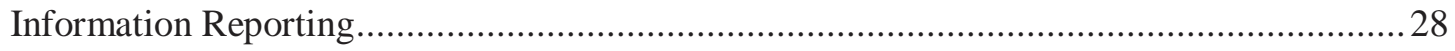

Multilateral Information Sharing or Withholding; International Cooperation..................28

Expanding Bilateral Information Exchange ..............................................................28

Unilateral Approaches: Withholding/Refund Approach; Increased Information

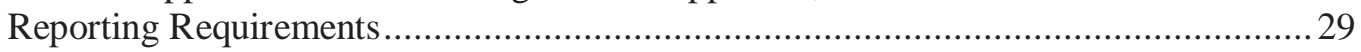




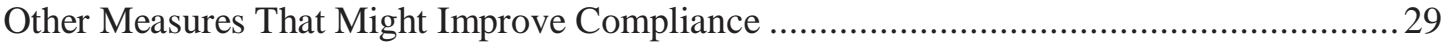

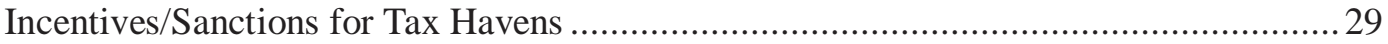

Revise the and Strengthen the Qualified Intermediary (QI)Program ............................. 30

Placing the Burden of Proof on the Taxpayer.............................................................. 31

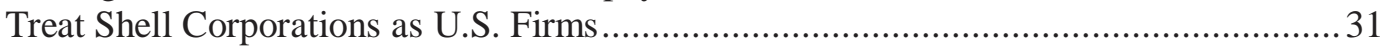

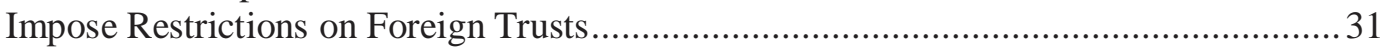

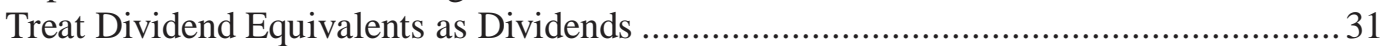

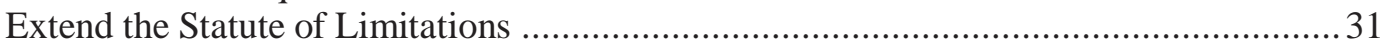

Greater Resources for the Internal Revenue Service to Focus on Offshore ...................... 32

Make Civil Cases Public as a Deterrent ......................................................................... 32

Revise Rules for FBAR (Foreign Bank Account Report) ……....................................... 32

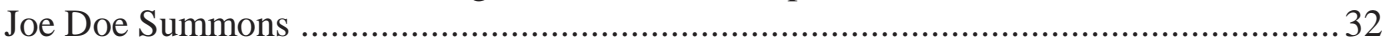

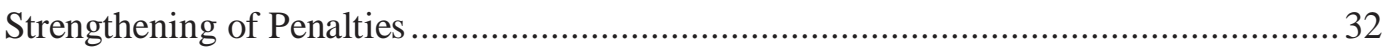

Address Tax Shelters; Codify Economic Substance Doctrine ...................................... 33

Regulate the Rules Used by States to Permit Incorporation......................................... 33

Make Suspicious Activity Reports Available to Civil Side of IRS ............................... 33

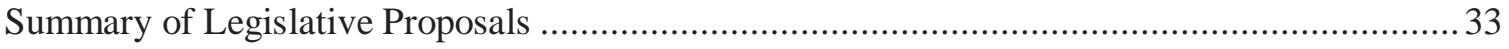

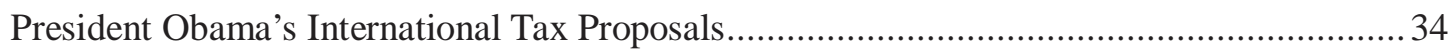

Provisions Affecting Multinational Corporations and Other Tax Law Changes............... 34

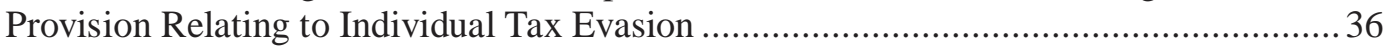

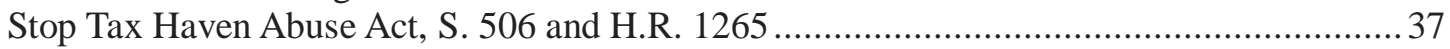

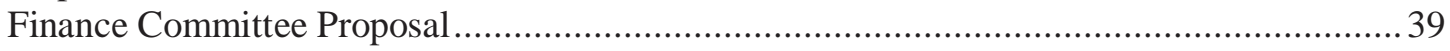

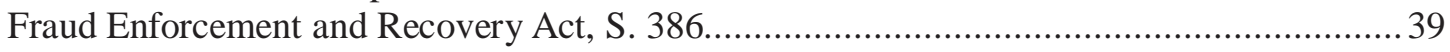

Incorporation Transparency and Law Enforcement Assistance Act, S. 569 ........................ 40

\section{Tables}

Table 1. Countries Listed on Various Tax Haven Lists ......................................................... 3

Table 2. U.S. Company Foreign Profits Relative to GDP, G-7 ............................................. 13

Table 3. U.S. Foreign Company Profits Relative to GDP, Larger Countries (GDP At Least $\$ 10$ billion) on Tax Haven Lists and the Netherlands .......................................................... 13

Table 4. U.S. Foreign Company Profits Relative to GDP, Small Countries on Tax Haven

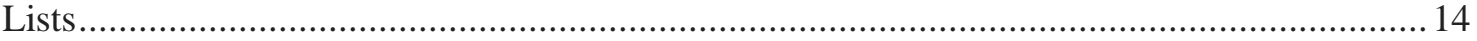

Table 5. Source of Dividends from "Repatriation Holiday": Countries Accounting for at Least $1 \%$ of Dividends .18

\section{Contacts}

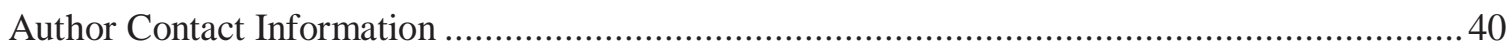




\section{Introduction}

The federal government loses both individual and corporate income tax revenue from the shifting of profits and income into low-tax countries. The revenue losses from this tax avoidance and evasion are difficult to estimate, but some have suggested that the annual cost of offshore tax abuses may be around $\$ 100$ billion per year. ${ }^{1}$ International tax avoidance can arise from wealthy individual investors and from large multinational corporations; it can reflect both legal and illegal actions.

Tax avoidance is sometimes used to refer to a legal reduction in taxes, while evasion refers to tax reductions that are illegal. Both types are discussed in this report, although the dividing line is not entirely clear. A multinational firm that constructs a factory in Ireland rather than in the United States to take advantage of low Irish corporate tax rates is engaged in avoidance, while a U.S. citizen who sets up a secret bank account in the Caribbean and does not report the interest income is engaged in evasion. There are, however, many activities, particularly by corporations, that are often referred to as avoidance but could be classified as evasion. One example is transfer pricing, where firms charge low prices for sales to low-tax affiliates but pay high prices for purchases from them. If these prices, which are supposed to be at arms-length, are set at an artificial level, then this activity might be viewed by some as evasion, even if such pricing is not overturned in court because evidence to establish pricing is not available.

Most of the international tax reduction of individuals reflects evasion, and this amount has been estimated to range from about $\$ 40$ billion to about $\$ 70$ billion a year. ${ }^{2}$ This evasion occurs in part because the United States does not withhold tax on many types of passive income (such as interest) paid to foreign entities; if U.S. individuals can channel their investments through a foreign entity and do not report the holdings of these assets on their tax returns, they evade a tax that they are legally required to pay. In addition, individuals investing in foreign assets may not report income from them.

Corporate tax reductions arising from profit shifting have also been estimated. As discussed below, estimates of the revenue losses from corporate profit shifting vary substantially, ranging from about $\$ 10$ billion to about $\$ 60$ billion.

In addition to differentiating between individual and corporate activities, and evasion and avoidance, there are also variations in the features used to characterize tax havens. Some restrictive definitions would limit tax havens to those countries that, in addition to having low or non-existent tax rates on some types of income, also have such other characteristics as the lack of transparency, bank secrecy and the lack of information sharing, and requiring little or no economic activity for an entity to obtain legal status. A definition incorporating compounding factors such as these was used by the Organization for Economic Development and Cooperation (OECD) in their tax shelter initiative. Others, particularly economists, might characterize as a tax haven any low-tax country with a goal of attracting capital, or simply any country that has low or non-existent taxes. We address tax havens in their broader sense as well as in their narrower sense in this report.

\footnotetext{
${ }^{1}$ See U.S. Senate Subcommittee on Investigations, Staff Report on Dividend Tax Abuse, September 11, 2008.

${ }^{2}$ Joseph Guttentag and Reven Avi-Yonah, "Closing the International Tax Gap, In Max B. Sawicky, ed. Bridging the Tax Gap: Addressing the Crisis in Federal Tax Administration, Washington, DC, Economic Policy Institute, 2005.
} 
While international tax avoidance can be differentiated by whether it is associated with individuals or corporations, whether it is illegal evasion or legal avoidance, and whether it arises in a tax haven narrowly defined or broadly defined, it can also be characterized by what measures might be taken to reduce this loss. In general, revenue losses from individual taxes are more likely to be associated with evasion and more likely to be associated with narrowly defined tax havens, while corporate tax avoidance occurs in both narrowly and broadly defined tax havens and can arise from either legal avoidance or illegal evasion. Evasion is often a problem of lack of information, and remedies may include resources for enforcement, along with incentives and sanctions designed to increase information sharing, and possibly a move towards greater withholding. Avoidance may be more likely to be remedied with changes in the tax code.

Several legislative proposals have been advanced that address international tax issues. President Obama has proposed several international corporate tax revisions which relate to multinational corporations, including profit shifting, as well as individual tax evasion. Some of these provisions had earlier been included in a bill introduced in the $110^{\text {th }}$ Congress by Chairman Rangel of the Ways and Means Committee (H.R. 3970). The Senate Permanent Subcommittee on Investigations has been engaged in international tax investigations since 2001, holding hearings proposing legislation. ${ }^{3}$ In the $11^{\text {th }}$ Congress, the Stop Tax Haven Abuse Act, S. 506, has been introduced by the Chairman of that committee, Senator Levin, with a companion bill, H.R. 1265, introduced by Representative Doggett. The Senate Finance Committee also has circulated draft proposals addressing individual tax evasion issues. S. 386, introduced by Chairman Leahy of the Senate Judiciary Committee, would expand the money-laundering provisions to include tax evasion, and provide additional funding for the tax division of the Justice Department. S. 569, also introduced by Chairman Levin, would impose requirements on the states for determination of beneficial owners of corporations formed under their laws. This proposal has implications for the potential use of incorporation in certain states as a part of an international tax haven plan.

The first section of this report reviews what countries might be considered tax havens, including a discussion of the Organization for Economic Development and Cooperation (OECD) initiatives and lists. The next two sections discuss, in turn, the corporate profit-shifting mechanisms and evidence on the existence and magnitude of profit shifting activity. The following two sections provide the same analysis for individual tax evasion. The report concludes with overviews of alternative policy options and a summary of specific legislative proposals.

\section{Where Are the Tax Havens?}

There is no precise definition of a tax haven. The OECD initially defined the following features of tax havens: no or low taxes, lack of effective exchange of information, lack of transparency, and no requirement of substantial activity. ${ }^{4}$ Other lists have been developed in legislative proposals and by researchers. There are also a number of other jurisdictions that have been identified as having tax haven characteristics.

\footnotetext{
${ }^{3}$ For a chronology, see Martin Sullivan, "Proposals to Fight Offshore Tax Evasion, Part 3," Tax Notes May 4, 2009 , p. 517.

${ }^{4}$ Organization for Economic Development and Cooperation, Harmful Tax Competition: An Emerging Global Issue, 1998, p. 23.
} 


\section{Formal Lists of Tax Havens}

The OECD created an initial list of tax havens in 2000. A similar list was used in S. 396, introduced in the $110^{\text {th }}$ Congress, which would treat firms incorporated in certain tax havens as domestic companies; the only difference between this list and the OECD list was the exclusion of the U.S. Virgin Islands from the list in S. 396. Legislation introduced in the $111^{\text {th }}$ Congress to address tax haven abuse (S. 506, H.R. 1265) uses a different list taken from IRS court filings, but has many countries in common. The definition by the OECD excluded low- tax jurisdictions, some of which are OECD members, that were thought by many to be tax havens, such as Ireland and Switzerland. These countries were included in an important study of tax havens by Hines and Rice. ${ }^{5} \mathrm{GAO}$ also provided a list. ${ }^{6}$

Table 1 lists the countries that appear on various lists, arranged by geographic location. These tax havens tend to be concentrated in certain areas, including the Caribbean and West Indies and Europe, locations close to large developed countries. There are 50 altogether.

\section{Table I. Countries Listed on Various Tax Haven Lists}

\begin{tabular}{|c|c|}
\hline Caribbean/West Indies & 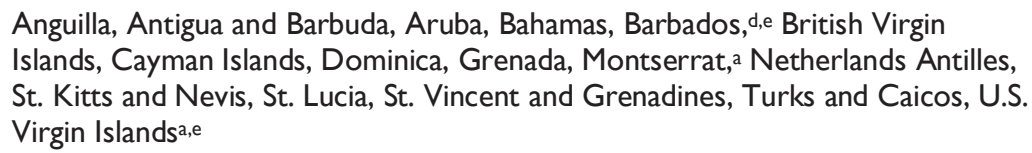 \\
\hline Central America & Belize,e Costa Rica,b,c Panamae \\
\hline Coast of East Asia & Hong Kong,a,b,e Macau,a,b,e Singapore \\
\hline Europe/Mediterranean & $\begin{array}{l}\text { Andorra, }{ }^{a} \text { Channel Islands (Guernsey and Jersey), e Cyprus, e Gibralter, Isle of } \\
\text { Man,e Ireland,a,b,e Liechtenstein, Luxembourg,a,be Malta,e Monaco,a San Marino,a,e } \\
\text { Switzerlanda,b }\end{array}$ \\
\hline Indian Ocean & Maldives,a,d,e Mauritius,a,c,e Seychelles a,e \\
\hline Middle East & Bahrain, Jordan,a,b,e Lebanon a,b,e \\
\hline North Atlantic & Bermudae \\
\hline Pacific, South Pacific & Cook Islands, Marshall Islands, a Samoa, Nauru, c Niue,a,c Tonga, ${ }^{a, c, d, e ~ V a n u a t u ~}$ \\
\hline West Africa & Liberia \\
\hline
\end{tabular}

Sources: Organization for Economic Development and Cooperation (OECD), Towards Global Tax Competition, 2000; Dhammika Dharmapala and James R. Hines, "Which Countries Become Tax Havens?" December 2006; Tax Justice Network, "Identifying Tax Havens and Offshore Finance Centers: http://www.taxjustice.net/cms/ upload/pdf/Identifying_Tax_Havens_Jul_07.pdf. The OECD's "gray" list as of April 2, 2009 is posted at http://www.oecd.org/dataoecd/38/I4/42497950.pdf. The countries in Table I are the same as the countries, with the exception of Tonga, in a recent GAO Report, International Taxation: Large U.S. Corporations and Federal Contractors with Subsidiaries in Jurisdictions Listed as Tax Havens or Financial Privacy Jurisdictions, GAO-09-I57, December 2008.

Notes: St. Kitts may also be referred to as St. Christopher. The Channel Islands are sometimes listed as a group and sometimes Jersey and Guernsey are listed separately. S. 506 and H.R. I 245 specifically mention Jersey, and also refer to Gurensey/Sark/Alderney, the latter two are islands associated with Guernsey.

\footnotetext{
5 J.R. Hines and E.M. Rice, "Fiscal Paradise: Foreign Tax havens and American Business," Quarterly Journal of Economics, vol. 109, February 1994, pp. 149-182.

${ }^{6}$ Government Accountability Office, International Taxation: Large U.S. Corporations and Federal Contractors with Subsidiaries in Jurisdictions Listed as Tax Havens or Financial Privacy Jurisdictions, GAO-op-157, December 2008.
} 
a. Not included in S. 506, H.R. 1245.

b. Not included in original OECD tax haven list.

c. Not included in Hines and Rice (1994)

d. Removed from OECD's List; Subsequently determined they should not be included.

e. Not included in OECD's "gray" list as of July 8, 2009; currently on the OECD "white" list. Note that the "gray" list is divided into countries that are tax havens and countries that are other financial centers. The latter classification includes three countries listed in Table I (Luxembourg, Singapore, and Switzerland) and five that are not (Austria, Belgium, Brunei, Chile, and Guatemala). Of the four countries moved from the "black" to the "gray" list, one, Costa Rica, is in Table I and three, Malaysia, Uruguay and the Philippines are not.

\section{Developments in the OECD Tax Haven List}

The OECD list, the most prominent list, has changed over time. Nine of the countries in Table 1 did not appear on the earliest OECD list. These countries not appearing on the original list tend to be more developed larger countries and include some that are members of the OECD (e.g., Switzerland and Luxembourg).

It is also important to distinguish between OECD's original list and its blacklist. OECD subsequently focused on information exchange and removed countries from a "blacklist if they agree to cooperate." OECD initially examined 47 jurisdictions and identified a number as not meeting the criteria for a tax haven; it also initially excluded six countries with advance agreements to share information (Bermuda, the Cayman Islands, Cyprus, Malta, Mauritius, and San Marino). The 2000 OECD blacklist included 35 countries; this list did not include the six countries eliminated due to advance agreement. The OECD had also subsequently determined that three countries should not be included in the list of tax havens (Barbados, the Maldives, and Tonga). Over time, as more tax havens made agreements to share information, the blacklist dwindled until it included only three countries: Andorra, Liechtenstein, and Monaco.

A study of the OECD initiative on global tax coordination by Sharman, also discussed in a book review by Sullivan, argues that the reduction in the OECD list was not because of actual progress towards cooperation so much as due to the withdrawal of U.S. support in 2001, which resulted in the OECD focusing on information on request and not requiring reforms until all parties had signed on. ${ }^{7}$ This analysis suggests that the large countries were not successful in this initiative to rein in on tax havens. A similar analysis by Spencer and Sharman suggests little real progress has been made in reducing tax haven practices. ${ }^{8}$

Interest in tax haven actions has increased recently. The scandals surrounding the Swiss bank UBS AG (UBS) and the Liechtenstein Global Trust Group (LGT), which led to legal actions by the United States and other countries, focused greater attention on international tax issues, primarily information reporting and individual evasion. ${ }^{9}$ The credit crunch and provision of

\footnotetext{
${ }^{7}$ J. C. Sharman, Havens in a Storm, The Struggle for Global Tax Regulation, Cornell University Press, Ithaca, New York, 2006; Martin A. Sullivan, "Lessons From the Last War on Tax Havens," Tax Notes, July 30, 2007, pp. 327-337.

${ }^{8}$ David Spencer and J.C. Sharman, International Tax Cooperation, Journal of International Taxation, published in three parts in December 2007, pp. 35-49, January 2008, pp. 27-44, 64, February 2008, pp. 39-58.

${ }^{9}$ For a discussion of these cases see Joint Committee on Taxation Tax Compliance and Enforcement Issues With Respect to Offshore Entities and Accounts, JCX-23-09, March 30, 2009. The discussion of UBS begins on p. 31 and the discussion of LGT begins on p. 40. This document also discusses the inquiries of the Permanent Subcommittee on (continued...)
} 
public funds to banks has also heightened public interest. The tax haven issue was revived recently with a meeting of the G20 industrialized and developing countries that proposed sanctions, and a number of countries began to indicate commitments to information sharing agreements. ${ }^{10}$

The OECD currently has three lists: a "white list" of countries implementing an agreed-upon standard, a "gray" list of countries that have committed to such a standard, and a "black" list of countries that have not committed. On April 7, 2009, the last four countries on the "black list, which were countries not included on the original OECD list, Costa Rica, Malaysia, the Philippines and Uruguay, were moved to the "gray" list. ${ }^{11}$ The gray list includes countries not identified as tax havens but as "other financial centers." According to news reports, Hong Kong and Macau were omitted from the OECD's list because of objections from China, but are mentioned in a footnote as having committed to the standards; they also noted that a "recent flurry of commitments brought 11 jurisdictions, including Austria, Liechtenstein, Luxembourg, Singapore, and Switzerland into the committed category." 12

Many countries that were listed on the OECD's original blacklist protested because of the negative publicity and many now point to having signed agreements to negotiate tax information exchange agreements (TIEA) and some have negotiated agreements. The identification of tax havens can have legal ramifications if laws and sanctions are contingent on that identification, as is the case of some current proposals in the United States and of potential sanctions by international bodies.

\section{Other Jurisdictions With Tax Haven Characteristics}

Criticisms have been made by a range of commentators that many countries are tax havens or have aspects of tax havens and have been overlooked. These jurisdictions include major countries such as the United States, the UK, the Netherlands, Denmark, Hungary Iceland, Israel, Portugal, and Canada. Attention has also been directed at three states in the United States, Delaware, Nevada, and Wyoming. Finally there are a number of smaller countries or areas in countries, such as Campione d'Italia, an Italian town located within Switzerland, that have been characterized as tax havens.

A country not on the list in Table 1, but which is often considered a tax haven, especially for corporations, is the Netherlands, which allows firms to reduce taxes on dividends and capital gains from subsidiaries and has a wide range of treaties that reduce taxes. ${ }^{13}$ In 2006 , for example,

\footnotetext{
(...continued)

Investigations of the Senate Homeland Security Committee relating to these cases.

${ }^{10}$ Anthony Faiola and Mary Jordan, "Tax-Haven Blacklist Stirs Nations: After G-20 Issues mandate, Many Rush to Get Off Roll," Washington Post, April 4, p. A7.

${ }^{11}$ This announcement by the OECD was posted at http://www.oecd.org/document/0/ 0,3343,en_2649_34487_42521280_1_1_1_1,00.html.

${ }^{12}$ David D. Stewart, “G-20 Declares End to Bank Secrecy as OECD Issues Tiered List,” Tax Notes, April 6, 2009, pp. 38-39.

${ }^{13}$ Micheil van Dijk, Francix Weyzig, and Richard Murphy, The Netherlands: A Tax Haven? SOMO (Centre for Research on Multinational Corporations), Amersterdam, 2007.
} 
Bono and other members of the $\mathrm{U} 2$ band moved their music publishing company from Ireland to the Netherlands after Ireland changed its tax treatment of music royalties. ${ }^{14}$

Some have identified the United States and the United Kingdom as having tax haven characteristics. Luxembourg Prime Minister Jean-Claude Junker urged other EU member states to challenge the United States for tax havens in Delaware, Nevada, and Wyoming. ${ }^{15}$ One website offering offshore services mentions, in their view, several overlooked tax havens which include the United States, United Kingdom, Denmark, Iceland, Israel, and Portugal's Madeira Island. ${ }^{16}$ (Others on their list and not listed in Table 1 were Hungary, Brunei, Uruguay, and Labuan (Malaysia)). ${ }^{17}$ In the case of the United States the article mentions the lack of reporting requirements and the failure to tax interest and other exempt passive income paid to foreign entities, the limited liability corporation which allows a flexible corporate vehicle not subject to taxation, and the ease of incorporating in certain states (Delaware, Nevada, and Wyoming).

Another website includes in its list of tax havens Delaware, Wyoming, and Puerto Rico, along with other jurisdictions not listed in Table 1: the Netherlands, Campione d'Italia, a separate listing for Sark (identified as the only remaining "fiscal paradise"), the United Kingdom, and a coming discussion for Canada. ${ }^{18}$ Sark is an island country associated with Guernsey, part of the Channel Islands, and Campione d'Italia is an Italian town located within Switzerland.

The Economist reported a study by a political scientist experimenting with setting up sham corporations; the author succeeded in incorporating in Wyoming and Nevada, as well as the United Kingdom and several other places. ${ }^{19}$ Michael McIntyre discusses three U.S. practices that aid international evasion: the failure to collect information on tax exempt interest income paid to foreign entities, the system of foreign institutions that act as qualified intermediaries (see discussion below) but do not reveal their clients, and the practices of states such as Delaware and Wyoming that allow people to keep secret their identities as stockholder or depositor. ${ }^{20}$

In a meeting in late April 2009, Eduardo Silva, of the Cayman Islands Financial Services Association, claimed that Delaware, Nevada, Wyoming, and the United Kingdom were the greatest offenders with respect to, among other issues, tax fraud. He suggested that Nevada and Wyoming were worse than Delaware because they permit companies to have bearer shares, which allows anonymous ownership. A U.S. participant at the conference noted that legislation in the United States, S. 569, would require disclosure of beneficial owners in the United States. ${ }^{21}$

\footnotetext{
${ }^{14}$ Fergal O’Brien, “Bono, Preacher on Poverty, Tarnishes Halo Irish Tax Move,” October 15, 2006, Bloomberg.com, http://bloomberg.com/apps/news?pid=20601109\&refer=home\&sid=aef6sR60oDgM\#.

${ }^{15}$ Charles Gnaedinger, "Luxembourg P.M Calls out U.S. States as Tax Havens” Tax Notes International, April 6, 2009, p. 13.

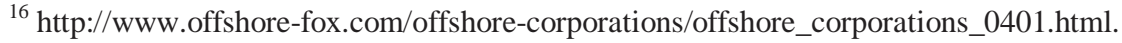

${ }^{17}$ Another offshore website lists in addition to the countries in Table 1 Austria, Campione d'Italia, Denmark, Hungary, Iceland, Madeira, Russian Federation, United Kingdom, Brunei, Dubai, Lebanon, Canada, Puerto Rico, South Africa, New Zealand, Labuan, Uruguay, and the United States. See http://www.mydeltaquest.com/english/.

${ }^{18} \mathrm{http}: / / w w w . o f f s h o r e-m a n u a l . c o m / t a x h a v e n s /$.

19 "Haven Hypocrisy," The Economist, March 26, 2008.

${ }^{20}$ Michael McIntyre, “A Program for International Tax Reform,” Tax Notes, February 23, 2009, pp. 1021-1026.

${ }^{21}$ Charles Gnaedinger, “U.S.,Cayman Islands Debate Tax Haven Status,” Tax Notes, May 4, 2009, p. 548-545.
} 
In addition, any country with a low tax rate could be considered as a potential location for shifting income to. In addition to Ireland, three other countries in the OECD not included in Table $\mathbf{1}$ have tax rates below 20\%: Iceland, Poland, and the Slovak Republic. ${ }^{22}$ Most of the eastern European countries not included in the OECD have tax rates below $20 \%{ }^{23}$

The Tax Justice Network probably has the largest list of tax havens, and includes some specific cities and areas. ${ }^{24}$ In addition to the countries listed in Table 1, they include in the Americas and Caribbean, New York and Uruguay; in Africa, Mellila, Sao Tome e Principe, Somalia, and South Africa; in the Middle East and Asia, Dubai, Labuan (Malaysia), Tel Aviv, and Taipei; in Europe, Alderney, Belgium, Campione d'Italia, City of London, Dublin, Ingushetia, Madeira, Sark, Trieste, Turkish Republic of Northern Cyprus, and Frankfurt; and in the Indian and Pacific oceans, the Marianas. The only county listed in Table 1 and not included in their list was Jordan.

\section{Methods of Corporate Tax Avoidance}

U.S. multinationals are not taxed on income earned by foreign subsidiaries until it is repatriated to the U.S. parent as dividends, although some passive and related company income that is easily shifted is taxed currently under anti-abuse rules referred to as Subpart F. (Foreign affiliates or subsidiaries that are majority owned U.S. owned are referred to as controlled foreign corporations, or CFCs, and many of these related firms are wholly owned.) Taxes on income that is repatriated (or, less commonly, earned by branches and taxed currently) is allowed a credit for foreign income taxes paid. (A part of a parent company treated as a branch is not a separate entity for tax purposes, and all income is part of the parent's income.)

Foreign tax credits are limited to the amount of tax imposed by the United States, so that they, in theory, cannot offset taxes on domestic income. This limit is imposed on an overall basis, allowing excess credits in high-tax countries to offset U.S. tax liability on income earned in lowtax countries, although separate limits apply to passive and active income. Other countries either employ this system of deferral and credit or, more commonly, exempt income earned in foreign jurisdictions. Most countries have some form of anti-abuse rules similar to Subpart F.

If a firm can shift profits to a low-tax jurisdiction from a high-tax one, its taxes will be reduced without affecting other aspects of the company. Tax differences also affect real economic activity, which in turn affects revenues, but it is this artificial shifting of profits that is the focus of this report. $^{25}$

Because the United States taxes all income earned in its borders as well as imposing a residual tax on income earned abroad by U.S. persons, tax avoidance relates both to U.S. parent companies shifting profits abroad to low-tax jurisdictions and the shifting of profits out of the United States by foreign parents of U.S. subsidiaries. In the case of U.S. multinationals, one study suggested that about half the difference between profitability in low-tax and high-tax countries, which could arise from artificial income shifting, was due to transfers of intellectual property (or intangibles)

\footnotetext{
${ }^{22}$ http://www.oecd.org/document/60/0,3343,en_2649_34897_1942460_1_1_1_1,00.html.

${ }^{23}$ For tax rates see http://www.worldwide-tax.com/index.asp\#partthree.

${ }^{24}$ Tax Justice Network, Tax Us if You Can, September, 2005.

${ }^{25}$ Effects on economic activity are addressed in CRS Report RL34115, Reform of U.S. International Taxation: Alternatives, by Jane G. Gravelle.
} 
and most of the rest through the allocation of debt. ${ }^{26}$ However, a study examining import and export prices suggests a very large effect of transfer pricing in goods (as discussed below). ${ }^{27}$ Some evidence of the importance of intellectual property can also be found from the types of firms that repatriated profits abroad following a temporary tax reduction enacted in 2004; a third of the repatriations were in the pharmaceutical and medicine industry and almost $20 \%$ in the computer and electronic equipment industry. ${ }^{28}$

\section{Allocation of Debt and Earnings Stripping}

One method of shifting profits from a high-tax jurisdiction to a low-tax one is to borrow more in the high-tax jurisdiction and less in the low-tax one. This shifting of debt can be achieved without changing the overall debt exposure of the firm. A more specific practice is referred to as earnings stripping where either debt is associated with related firms or unrelated debt is not subject to tax by the recipient. As an example of the former earnings stripping method, a foreign parent may lend to its U.S. subsidiary. Alternatively, an unrelated foreign borrower not subject to tax on U.S. interest income might lend to a U.S. firm.

The U.S. tax code currently contains provisions to address interest deductions and earnings stripping. It applies an allocation of the U.S. parent's interest for purposes of the limit on the foreign tax credit. The amount of foreign source income is reduced when part of U.S. interest is allocated and the maximum amount of foreign tax credits taken is limited, a provision that affects firms with excess foreign tax credits. ${ }^{29}$ There is no allocation rule, however, to address deferral, so that a U.S. parent could operate its subsidiary with all equity finance in a low-tax jurisdiction and take all of the interest on the overall firm's debt as a deduction. A bill introduced in 2007 (H.R. 3970) by Chairman Rangel of the Ways and Means Committee would introduce such an allocation rule, so that a portion of interest and other overhead costs would not be deducted until the income is repatriated. ${ }^{30}$ This provision is also included in President Obama's proposals for international tax revision.

While allocation-of-interest approaches could be used to address allocation of interest to high-tax countries in the case of U.S. multinationals, they cannot be applied to U.S. subsidiaries of foreign corporations. To limit the scope of earnings stripping in either case, the United States has thin capitalization rules. (Most of the United States' major trading partners have similar rules.) A section of the Internal Revenue Code (163(j)) applies to a corporation with a debt-to-equity ratio above 1.5 to 1 and with net interest exceeding 50\% of adjusted taxable income (generally taxable income plus interest plus depreciation). Interest in excess of the $50 \%$ limit paid to a related corporation is not deductible if the corporation is not subject to U.S. income tax. This interest restriction also applies to interest paid to unrelated parties that are not taxed to the recipient.

\footnotetext{
${ }^{26}$ Harry Grubert, "Intangible Income, Intercompany Transactions, Income Shifting and the Choice of Locations," National Tax Journal, vol. 56, March 2003, Part II, pp. 221-242.

${ }^{27}$ Simon J. Pak and John S. Zdanowicz, U.S. Trade With the World, An Estimate of 2001 Lost U.S. Federal Income Tax Revenues Due to Over-Invoiced Imports and Under-Invoiced Exports, October 31, 2002.

${ }^{28}$ CRS Report R40178, Tax Cuts on Repatriation Earnings as Economic Stimulus: An Economic Analysis, by Donald J. Marples and Jane G. Gravelle.

${ }^{29}$ In 2004 the interest allocation rules were changed to allocate worldwide interest, but the implementation of that provision was delayed and has not yet taken place. See CRS Report RL34494, The Foreign Tax Credit's Interest Allocation Rules, by Jane G. Gravelle and Donald J. Marples.

${ }^{30}$ See CRS Report RL34249, The Tax Reduction and Reform Act of 2007: An Overview, by Jane G. Gravelle.
} 
The possibility of earnings stripping received more attention after a number of U.S. firms inverted, that is, arranged to move their parent firm abroad so that U.S. operations became a subsidiary of that parent. The American Jobs Creation Act (AJCA) of 2004 addressed the general problem of inversion by treating firms that subsequently inverted as U.S. firms. During consideration of this legislation there were also proposals for broader earnings stripping restrictions as an approach to this problem that would have reduced the excess interest deductions. This general earnings stripping proposal was not adopted. However, the AJCA mandated a Treasury Department study on this and other issues; that study focused on U.S. subsidiaries of foreign parents and was not able to find clear evidence on the magnitude. ${ }^{31}$

An noted in the Treasury's mandated study, there is relatively straightforward evidence that U.S. multinationals allocate more interest to high-tax jurisdictions, but it is more difficult to assess earnings stripping by foreign parents of U.S. subsidiaries, because the entire firm's accounts are not available. The Treasury study focused on this issue and used an approach that had been used in the past of comparing these subsidiaries to U.S. firms. The study was not able to provide conclusive evidence about the shifting of profits out of the United States due to high leverage rates for U.S. subsidiaries of foreign firms but did find evidence of shifting for inverted firms.

\section{Transfer Pricing}

The second major way that firms can shift profits from high-tax to low-tax jurisdictions is through the pricing of goods and services sold between affiliates. To properly reflect income, prices of goods and services sold by related companies should be the same as the prices that would be paid by unrelated parties. By lowering the price of goods and services sold by parents and affiliates in high-tax jurisdictions and raising the price of purchases, income can be shifted.

An important and growing issue of transfer pricing is with the transfers to rights to intellectual property, or intangibles. If a patent developed in the U.S. is licensed to an affiliate in a low-tax country (such as one in Ireland) income will be shifted if the royalty or other payment is lower than the true value of the license. For many goods there are similar products sold or other methods (such as cost plus a mark up) that can be used to determine whether prices are set appropriately. Intangibles, such as new inventions or new drugs, tend not to have comparables, and it is very difficult to know the royalty that would be paid in an arms-length price. Therefore, intangibles represent particular problems for policing transfer pricing.

Investment in intangibles is favorably treated in the United States because costs, other than capital equipment and buildings, are expensed for research and development, which is also eligible for a tax credit. In addition, advertising to establish brand names is also deductible. Overall these treatments tend to produce an effective low, zero, or negative tax rate for overall investment in intangibles. Thus, there are significant incentives to make these investments in the United States. On average, the benefit of tax deductions or credits when making the investment tend to offset the future taxes on the return to the investment. However, for those investments that tend to be successful, it is advantageous to shift profits to a low-tax jurisdiction, so that there are tax savings on investment and little or no tax on returns. As a result, these investments can be subject to negative tax rates, or subsidies, which can be significant.

${ }^{31}$ U.S. Department of Treasury, Report to Congress on Earnings Stripping, Transfer Pricing and U.S. Income Tax Treaties, November 2007. 
Transfer pricing rules with respect to intellectual property are further complicated because of cost sharing agreements, where different affiliates contribute to the cost. ${ }^{32}$ If an intangible is already partially developed by the parent firm, affiliates contribute a buy-in payment. It is very difficult to determine arms length pricing in these cases where a technology is partially developed and there is risk associated with the expected outcome. One study found some evidence that firms with cost sharing arrangements were more likely to engage in profit shifting. ${ }^{33}$

\section{Contract Manufacturing}

When a subsidiary is set up in a low-tax country and profit shifting occurs, as in the acquisition of rights to an intangible, a further problem occurs: this low-tax country may not be a desirable place to actually manufacture and sell the product. For example, an Irish subsidiary's market may be in Germany and it would be desirable to manufacture in Germany. But to earn profits in Germany with its higher tax rate does not minimize taxes. Instead the Irish firm may contract with a German firm as a contract manufacturer, who will produce the item for cost plus a fixed markup. Subpart $\mathrm{F}$ taxes on a current basis certain profits from sales income, so the arrangement must be structured to qualify as an exception from this rule. There are complex and changing regulations on this issue. ${ }^{34}$

\section{Check-the-Box, Hybrid Entities, and Hybrid Instruments}

Another technique for shifting profit to low-tax jurisdictions was greatly expanded with the "check-the-box" provisions. These provisions were originally intended to simplify questions of whether a firm was a corporation or partnership. Their application to foreign circumstances, through the "disregarded entity" rules has led to the expansion of hybrid entities, where an entity can be recognized as a corporation by one jurisdiction but not by another. For example, a U.S. parent's subsidiary in a low-tax country can lend to its subsidiary in a high-tax country, with the interest deductible because the high-tax country recognizes the firm as a separate corporation. Normally, interest received by the subsidiary in the low-tax country would be considered passive or "tainted" income subject to current U.S. tax under Subpart F. However, under check-the-box rules, the high-tax corporation can elect to be disregarded as a separate entity, and thus from the perspective of the United States there is no interest income paid because the two are the same entity. Check-the-box and similar hybrid entity operations can also be used to avoid other types of Subpart F income, for example from contract manufacturing arrangements. According to Sicular, this provision, which began as a regulation, has been effectively codified, albeit temporarily. ${ }^{35}$

Hybrid entities relate to issues other than Subpart F. For example, a reverse hybrid entity can be used to allow U.S. corporations to benefit from the foreign tax credit without having to recognize

\footnotetext{
32 The Treasury Department recently issued new proposed regulations relating to cost sharing arrangements. See Treasury Decision 9441, Federal Register, vol. 74, No. 2, January 5, 2009, pp. 340-391. These rules include a periodic adjustment which would, among other aspects, examine outcomes. See "Cost Sharing Periodic Payments Not Automatic, Officials Say," Tax Notes, February 23, 2009, p. 955.

${ }^{33}$ Michael McDonald, "Income Shifting from Transfer Pricing: Further Evidence from Tax Return Data," U.S. Department of the Treasury, Office of Tax Analysis, OTA Technical Working Paper 2, July 2008.

${ }^{34}$ See for example William W. Chip, “'Manufacturing' Foreign Base Company Sales Income,” Tax Notes, November 19, 2007, p. 803-808.

${ }^{35}$ See David R. Sicular, “The New Look-Through Rule: W(h)ither Subpart F? Tax Notes, April 23, 2007, pp. $349-378$ for a discussion of the look-through rules under Section 954(c)(6).
} 
the underlying income. As an example, a U.S. parent can set up a holding company in the Netherlands that is treated as a disregarded entity, and the holding company can own a corporation that is treated as a partnership in a foreign jurisdiction. Under flow through rules, the holding company is liable for the foreign tax and, because it is not a separate entity, the U.S. parent corporation is therefore liable, but the income can be retained in the foreign corporation that is viewed as a separate corporate entity from the U.S. point of view. In this case, the entity is structured so that it is a partnership for foreign purposes but a corporation for U.S. purposes. ${ }^{36}$

In addition to hybrid entities that achieve tax benefits by being treated differently in the United States and the foreign jurisdiction, there are also hybrid instruments that can avoid taxation by being treated as debt in one jurisdiction and equity in another. ${ }^{37}$

\section{Cross Crediting and Sourcing Rules for Foreign Tax Credits}

Income from a low-tax country that is received in the United States can escape taxes because of cross crediting: the use of excess foreign taxes paid in one jurisdiction or on one type of income to offset U.S. tax that would be due on other income. In some periods in the past the foreign tax credit limit was proposed on a country-by-country basis, although that rule proved to be difficult to enforce given the potential to use holding companies. Foreign tax credits have subsequently been separated into different baskets to limit cross crediting; these baskets were reduced from nine to two (active and passive) in the American Jobs Creation Act of 2004 (P.L. 108-357).

Because firms can choose when to repatriate income, they can arrange realizations to maximize the benefits of the overall limit on the foreign tax credit. That is, firms that have income from jurisdictions with taxes in excess of U.S. taxes can also elect to realize income from jurisdictions with low taxes and use the excess credits to offset U.S. tax due on that income. Studies suggest that between cross crediting and deferral, U.S. multinationals typically pay virtually no U.S. tax on foreign source income. ${ }^{38}$

This ability to reduce U.S. tax due to cross crediting is increased, it can be argued, because income that should be considered U.S. source income is treated as foreign source income, thereby raising the foreign tax credit limit. This includes income from U.S. exports which is U.S. source income, because a tax provision (referred to as the title passage rule) allows half of export income to be allocated to the country in which the title passes. Another important type of income that is considered foreign source and thus can be shielded with foreign tax credits is royalty income from active business, which has become an increasingly important source of foreign income. This benefit can occur in high-tax countries because royalties are generally deductible from income. (Note that the shifting of income due to transfer pricing of intangibles, advantageous in low-tax countries, is a different issue.) Interest income is another type of income that may benefit from this foreign tax credit rule.

\footnotetext{
${ }^{36}$ For a discussion of reverse hybrids see Joseph M. Calianno and J. Michael Cornett, "Guardian Revision: Proposed Regulations Attach Guardian and Reverse Hybrids," Tax Notes International, October 2006, pp. 305-316.

37 See Sean Foley, "U.S. Outbound: Cross border Hybrid Instrument Transactions to gain Increased Scrutiny During IRS Audit," http://www.internationaltaxreview.com/?Page=10\&PUBID=35\&ISS=24101\&SID=692834\&TYPE=20. Andrei Kraymal, International Hybrid Instruments: Jurisdiction Dependent Characterization, Houston Business and Tax Law Journal, 2005, http://www.hbtlj.org/v05/v05Krahmalar.pdf.

${ }^{38}$ Government Accountability Office, U.S. Multinational Corporations: Effective Tax Rates are Correlated With Where Income is Reported, GAO-08-950, August 2008.
} 
Since all of this income arises from investment in the United States, one could argue that this income is appropriately U.S. source income, or that, failing that, it should be put in a different foreign tax credit basket so that excess credits generated by dividends cannot be used to offset such income. Two studies, by Grubert and by Grubert and Altshuler have discussed this sourcing rule in the context of a proposal to eliminate the tax on active dividends. ${ }^{39}$ In that proposal, the revenue loss from exempting active dividends from U.S. tax would be offset by gains from taxes on royalties.

\section{The Magnitude of Corporate Profit Shifting}

This section examines the evidence on the existence and magnitude of profit shifting and the techniques that are most likely to contribute to it.

\section{Evidence on the Scope of Profit Shifting}

There is ample, and simple, evidence that profits appear in countries inconsistent with an economic motivation. This section first examines the profit share of income of controlled corporations compared to the share of gross domestic product. ${ }^{40}$ The first set of countries, acting as a reference point, are the remaining G-7 countries that are also the United States' major trading partners. They account for $32 \%$ of pre-tax profits and 38\% of rest-of-world gross domestic product. The second group of countries are larger countries from Table 1 (with GDP of at least $\$ 10$ billion), plus the Netherlands, which is widely considered a tax conduit for U.S. multinationals because of their holding company rules. These countries account for about $30 \%$ of earnings and 5\% of rest-of-world GDP. The third group of countries are smaller countries listed in Table 1, with GDP less than $\$ 10$ billion. These countries account for $14 \%$ of earnings and less than $1 \%$ of rest-of-world GDP.

As indicated in Table 2, income to GDP ratios in the large G-7 countries range from $0.2 \%$ to $2.6 \%$, the latter reflecting in part the United States' relationships with perhaps its closest trading partners. Overall, this income as a share of GDP is $0.6 \%$. Outside the United Kingdom and Canada, they are around 0.2 to $0.3 \%$ and do not vary with country size (Japan, for example, has over twice the GDP of Italy). Note also that Canada and the United Kingdom have also appeared on some tax haven lists and the larger income shares could partially reflect that. ${ }^{41}$

\footnotetext{
${ }^{39}$ Harry Grubert, “Tax Credits, Source Rules, Trade and electronic Commerce: Behavioral Margins and the Design of International Tax Systems. Tax Law Review, vol. 58, January 2005; also issued as a CESIFO Working Paper (No. 1366), December 2004.; Harry Grubert and Rosanne Altshuler, "Corporate Taxes in a World Economy: Reforming the Taxation of Cross-Border Income," in John W. Diamond and George Zodrow, eds., Fundamental Tax Reform: Issues, Choices and Implications, Cambridge, MIT Press, 2008.

${ }^{40}$ Data on earnings and profits of controlled foreign corporations are taken from Lee Mahoney and Randy Miller, Controlled Foreign Corporations 2004, Internal Revenue Service Statistics of Income Bulletin, Summer 2008, http://www.irs.ustreas.gov/pub/irs-soi/04coconfor.pdf. Data on GDP from Central Intelligence Agency, The World Factbook, https://www.cia.gov/library/publications/the-world-factbook. Most GDP data are for 2008 and based on the exchange rate but for some countries earlier years and data based on purchasing power parity were the only data available.

${ }^{41}$ One offshore website points out that Canada can be desirable as a place to establish a holding company; see Shelter Offshore,http://www.shelteroffshore.com/index.php/offshore/more/canada_offshore.
} 
Table 2. U.S. Company Foreign Profits Relative to GDP, G-7

\begin{tabular}{lc}
\hline Country & $\begin{array}{c}\text { Profits of U.S. Controlled Foreign } \\
\text { Corporations as a Percentage of GDP }\end{array}$ \\
\hline Canada & 2.6 \\
France & 0.3 \\
Germany & 0.2 \\
Italy & 0.2 \\
Japan & 0.3 \\
United Kingdom & 1.3 \\
Weighted Average & 0.6 \\
\hline
\end{tabular}

Source: CRS calculations, see text.

Table 3 reports the share for the larger tax havens listed in Table 1 for which data are available, plus the Netherlands. In general, U.S. source profits as a percentage of GDP are considerably larger than those in Table 2. In the case of Luxembourg, these profits are $18 \%$ of output. Shares are also very large in Cyprus and Ireland. In all but two cases, the shares are well in excess of those in Table 2.

Table 3. U.S. Foreign Company Profits Relative to GDP, Larger Countries (GDP At Least \$ 10 billion) on Tax Haven Lists and the Netherlands

\begin{tabular}{lcc}
\hline & Country & $\begin{array}{c}\text { Profits of U.S. Controlled Corporations } \\
\text { as a Percentage of GDP }\end{array}$ \\
\hline Costa Rica & 1.2 \\
Cyprus & 9.8 \\
Hong Kong & 2.8 \\
Ireland & 7.6 \\
Luxembourg & 18.2 \\
Netherlands & 4.6 \\
Panama & 3.0 \\
Singapore & 3.4 \\
Switzerland & 3.5 \\
Taiwan & 0.7 \\
\hline
\end{tabular}

Source: CRS calculations, see text.

Table $\mathbf{4}$ examines the small tax havens listed in Table 1 for which data are available. In three of the islands off the U.S. coast (in the Caribbean and Atlantic) profits are multiples of total GDP. Profits are well in excess of GDP in four jurisdictions. In other jurisdictions they are a large share of output. These numbers clearly indicate that the profits in these countries do not appear to derive from economic motives related to productive inputs or markets, but rather reflect income easily transferred to low-tax jurisdictions. 
Table 4. U.S. Foreign Company Profits Relative to GDP, Small Countries on Tax Haven Lists

\begin{tabular}{lc}
\hline \multicolumn{1}{c}{ Country } & $\begin{array}{c}\text { Profits of U.S. Controlled Corporations } \\
\text { as a Percentage of GDP }\end{array}$ \\
\hline Bahamas & 43.3 \\
Barbados & 13.2 \\
Bermuda & 645.7 \\
British Virgin Islands & 354.7 \\
Cayman Islands & 546.7 \\
Guernsey & 11.2 \\
Jersey & 35.3 \\
Liberia & 61.1 \\
Malta & 0.5 \\
Marshall Islands & 339.8 \\
Mauritius & 4.2 \\
Netherland Antilles & 8.9 \\
\hline
\end{tabular}

Source: CRS calculations, see text.

Evidence of profit shifting has been presented in many other studies. Grubert and Altshuler report that profits of controlled foreign corporations in manufacturing relative to sales in Ireland are three times the group mean. ${ }^{42} \mathrm{GAO}$ reported higher shares of pretax profits of U.S.

multinationals than of value added, tangible assets, sales, compensation or employees in low-tax countries such as Bermuda, Ireland, the UK Caribbean, Singapore, and Switzerland. ${ }^{43}$ Martin Sullivan reports the return on assets for 1998 averaged 8.4\% for U.S. manufacturing subsidiaries, but with returns of $23.8 \%$ in Ireland, $17.9 \%$ in Switzerland, and $16.6 \%$ in the Cayman Islands. ${ }^{44}$ More recently, he noted that of the ten countries that accounted for the most foreign multinational profits, the five countries with the highest manufacturing returns for 2004 (the Netherlands, Bermuda, Ireland, Switzerland, and China) all had tax rates below $12 \%$ while the five countries with lower returns (Canada, Japan, Mexico, Australia, and the United Kingdom) had tax rates in excess of $23 \% .^{45}$ A number of econometric studies of this issue have been done. ${ }^{46}$

\footnotetext{
${ }^{42}$ Harry Grubert and Rosanne Altshuler, "Corporate Taxes in a World Economy: Reforming the Taxation of CrossBorder Income," in John W. Diamond and George Zodrow, eds., Fundamental Tax Reform: Issues, Choices and Implications, Cambridge, MIT Press, 2008.

${ }^{43}$ Government Accountability Office, U.S. Multinational Corporations: Effective Tax Rates are Correlated With Where Income is Reported, GAO-08-950, August 2008.

${ }^{44}$ Martin Sullivan, U.S. Citizens Hide Hundreds of Billions in the Caymans, Tax Notes, May 24, 2004, p. 96.

${ }^{45}$ Martin Sullivan, "Extraordinary Profitability in Low-Tax Countries," Tax Notes, August 25, 2008, pp. 724-727.

${ }^{46}$ See James R. Hines, Jr., “Lessons from Behavioral Responses to International Taxation,” National Tax Journal, vol. 52 (June 1999): 305-322, and Joint Committee on Taxation, Economic Efficiency and Structural Analyses of Alternative U.S. Tax Policies for Foreign Direct Investment, JCX-55-08, June 25, 2008 for reviews. Studies are also discussed in U.S. Department of Treasury, The Deferral of Income of Earned Through Controlled Foreign Corporation, May, 2000, http://www.treas.gov/offices/tax-policy/library/subpartf.pdf.
} 


\section{Estimates of the Cost and Sources of Corporate Tax Avoidance}

There are no official estimates of the cost of international corporate tax avoidance, although a number of researchers have made estimates; nor are there official estimates of the individual tax gap. ${ }^{47}$ In general, the estimates are not reflected in the overall tax gap estimate. The magnitude of corporate tax avoidance has been estimated through a variety of techniques and not all are for total avoidance. Some address only avoidance by U.S. multinationals and not by foreign parents of U.S. subsidiaries. Some focus only on a particular source of avoidance.

Estimates of the potential revenue cost of income shifting by multinational corporations varies considerably, with estimates as high as $\$ 60$ billion. The only study by the IRS in this area is an estimate of the international gross tax gap (not accounting for increased taxes collected on audit) related to transfer pricing based on audits of returns. They estimated a cost of about $\$ 3$ billion, based on examinations of tax returns for 1996-1998. ${ }^{48}$ This estimate would reflect an estimate not of legal avoidance, but of non-compliance, and for reasons stressed in the study has a number of limitations. One of those is that an audit does not detect all non-compliance, and it would not detect avoidance mechanisms which are, or appear to be, legal.

Some idea of the potential magnitude of the revenue lost from profit shifting by U.S. multinationals might be found in the estimates of the revenue gain from eliminating deferral. If most of the profit in low-tax countries has been shifted there to avoid U.S. tax rates, the projected revenue gain from ending deferral would provide an idea of the general magnitude of the revenue cost of profit shifting by U.S. parent firms. The Joint Committee on Taxation projects the revenue gain from ending deferral to be about $\$ 11$ billion in FY2010. ${ }^{49}$ This estimate could be either an overstatement or an understatement of the cost of tax avoidance. It could be an overstatement because some of the profits abroad accrue to real investments in countries that have lower tax rates than the United States and thus do not reflect artificial shifting. It could be an understatement because it does not reflect the tax that could be collected by the United States rather than foreign jurisdictions on profits shifted to low-tax countries. For example, Ireland has a tax rate of $12.5 \%$ and the United States a 35\% rate, so that ending deferral (absent behavioral changes) would only collect the excess of the U.S. tax over the Irish tax on shifted revenues, or about two-thirds of lost revenue.

The Administration's estimates for ending deferral are slightly larger, over $\$ 14$ billion. ${ }^{50}$ Altshuler and Grubert estimate for 2002 that the corporate tax could be cut to $28 \%$ if deferral were ended, and based on corporate revenue in that year the gain is about $\$ 11$ billion. ${ }^{51}$ That year was at a low point because of the recession; if the share remained the same, the gain would be around $\$ 13$ billion for 2004 and $\$ 26$ billion for 2007. All of these estimates are based on tax data.

\footnotetext{
${ }^{47}$ This point is made by The Treasury Inspector General for Tax administration, "A Combination of Legislative Actions and Increased IRS Capability and Capacity are Required to Reduce the Multi-billion Dollar U.S. International Tax Gap," January 27 2009, 2009-I-R001.

${ }^{48}$ U.S. Department of the Treasury, IRS, Report on the Application and Administration of Section 482, 1999.

${ }^{49}$ Joint Committee on Taxation, Estimates of Federal Tax Expenditures for 2008-2012, October 31, 2008.

${ }^{50}$ Budget for FY2010, Analytical Perspectives, p. 293.

${ }^{51}$ Harry Grubert and Rosanne Altshuler, "Corporate Taxes in the World Economy," in Fundamental Tax Reform: Issues, Choices, and Implications ed. John W. Diamond and George R. Zodrow, Cambridge, MIT Press, 2008.
} 
Researchers have looked at differences in pretax returns and estimated the revenue gain if returns were equated. This approach should provide some estimates of the magnitude of overall profitshifting for multinationals, whether through transfer pricing, leveraging, or some other technique. Martin Sullivan, using Commerce Department data, estimates that, based on differences in pretax returns, the cost for 2004 was between $\$ 10$ and $\$ 20$ billion. Sullivan subsequently reports an estimated \$17 billion increase in revenue loss from profit shifting between 1999 and 2004, which suggests that earlier number may be too small. ${ }^{52}$ Sullivan suggests that the growth in profit shifting may be due to check-the-box. Christian and Schultz, using rate of return on assets data from tax returns, estimated $\$ 87$ billion was shifted in 2001, which, at a $35 \%$ tax rate, would imply a revenue loss of about $\$ 30$ billion. ${ }^{53}$ As a guide for potential revenue loss from avoidance, these estimates suffer from two limits. The first is the inability to determine how much was shifted out of high-tax foreign jurisdictions rather than the United States, which leads to a range of estimates. At the same time, if capital is mobile, economic theory indicates that the returns should be lower, the lower the tax rate. Thus the results could also understate the overall profit shifting and the revenue loss to the United States.

Pak and Zdanowicz examined export and import prices, and estimated that lost revenue due to transfer pricing of goods alone was $\$ 53$ billion in $2001 .^{54}$ This estimate should cover both U.S. multinationals and U.S. subsidiaries of foreign parents, but is limited to one technique. Kimberly Clausing, using regression techniques on cross country data, which estimated profits reported as a function of tax rates, estimated that revenues of over $\$ 60$ billion are lost for 2004 by applying a $35 \%$ tax rate to an estimated $\$ 180$ billion in corporate profits shifted out of the United States. ${ }^{55}$ She estimates that the profit shifting effects are twice as large as the effects from shifts in actual economic activity. This methodological approach differs from others which involve direct calculations based on returns or prices and is subject to the econometric limitations with cross country panel regressions. In theory, however, it had an overall of coverage of shifting (that is both outbound by U.S. parents of foreign corporations and inbound by foreign parents of U.S. corporations and covering all techniques).

Clausing and Avi-Yonah estimate the revenue gain from moving to a formula apportionment based on sales that is on the order of $\$ 50$ billion per year because the fraction of worldwide

\footnotetext{
52 "Shifting Profits Offshore Costs U.S. Treasury \$10 Billion or More,” Tax Notes, September 27, 2004, pp. 1477-1481; "U.S. Multinationals Shifting Profits Out of the United States," Tax Notes, March 10, 2008, pp. 1078-1082. \$75 billion in profits is artificially shifted abroad. If all of that income were subject to U.S. tax, it would result in a gain of \$26 billion for 2004. Sullivan acknowledges that there are many difficulties in determining the revenue gain. Some of this income might already be taxed under Subpart F, some might be absorbed by excess foreign tax credits, and the effective tax rate may be lower than the statutory rate. Sullivan concludes that an estimate of between $\$ 10$ billion and $\$ 20$ billion is appropriate. Altshuler and Grubert suggest that Sullivan's methodology may involve some double counting; however, their own analysis finds that multinationals saved \$7 billion more between 1997 and 2002 due to check the box rules. Some of this gain may have been at the cost of high-tax host countries rather than the United States, however. See Rosanne Altshuler and Harry Grubert, "Governments and Multinational Corporations in the Race to the Bottom," Tax Notes International, February 2006, pp. 459-474.

${ }^{53}$ Charles W. Christian and Thomas D. Schultz, ROA-Based Estimates of Income Shifting by Multinational Corporations, IRS Research Bulletin, 2005 http://www.irs.gov/pub/irs-soi/05christian.pdf.

${ }^{54}$ Simon J. Pak and John S. Zdanowicz, U.S. Trade With the World, An Estimate of 2001 Lost U.S. Federal Income Tax Revenues Due to Over-Invoiced Imports and Under-Invoiced Exports, October 31, 2002.

${ }^{55}$ Multinational Firm Tax Avoidance and U.S. Government Revenue, Kimberly Clausing, Working Paper, March 2008. Her method involved estimating the profit differentials as a function of tax rate differentials over the period 1982-2004 and then applying that coefficient to current earnings.
} 
income in the United States is smaller than the fraction of worldwide sales ${ }^{56}$ While this estimate is not an estimate of the loss from profit shifting (since sales and income could differ for other reasons) it is suggestive of the magnitude of total effects from profit shifting. A similar result was found by another study that applied formula apportionment based on an equal weight of assets, payroll, and sales. $^{57}$

It is very difficult to develop a separate estimate for U.S. subsidiaries of foreign multinational companies because there is no way to observe the parent firm and its other subsidiaries. Several studies have documented that these firms have lower taxable income and that some have higher debt to asset ratios than domestic firms. There are many other potential explanations these differing characteristics, however, and domestic firms that are used as comparisons also have incentives to shift profits when they have foreign operations. No quantitative estimate has been made ${ }^{58}$ However some evidence of earnings stripping for inverted firms was found. ${ }^{59}$

\section{Importance of Different Profit Shifting Techniques}

Some studies have attempted to identify the importance of techniques used for profit shifting. Grubert has estimated that about half of income shifting was due to transfer pricing of intangibles and most of the remainder to shifting of debt. ${ }^{60}$ In a subsequent study, Altshuler and Grubert find that multinationals saved $\$ 7$ billion more between 1997 and 2002 due to check the box rules. ${ }^{61}$ Some of this gain may have been at the cost of high-tax host countries rather than the United States, however.

Some of the estimates discussed here conflict with respect to the source of profit shifting. The Pak and Zdanowich estimates suggest that transfer pricing of goods is an important mechanism of tax avoidance, while Grubert suggests that the main methods of profit shifting are due to leverage and intangibles. The estimates for pricing of goods may, however, reflect errors, or money laundering motives rather than tax motives. Much of the shifting was associated with trade with

\footnotetext{
${ }^{56}$ Kimberly A. Clausing and Reuven S. Avi-Yonah, Reforming Corporate Taxation in a Global Economy: A Proposal to Adopt Formulary Apportionment, Brookings Institution: The Hamilton Project, Discussion paper 2007-2008, June 2007.

${ }^{57}$ Douglas Shackelford and Joel Slemrod, "The Revenue Consequences of Using Formula apportionment to Calculate U.S. and Foreign Source Income: A Firm Level Analysis," International Tax and Public Finance, vol. 5, no. 1, 1998, pp. 41-57.

${ }^{58}$ These studies are discussed and new research presented in U.S. Department of Treasury, Report to Congress on Earnings Stripping, Transfer Pricing and U.S. Income Tax Treaties, November 2007. One study used a different approach, examining taxes of firms before and after acquisition by foreign versus domestic acquirers, but the problem of comparison remains and the sample was very small; that study found no differences. See Jennifer L. Blouin, Julie H. Collins, and Douglas A. Shackelford, "Does Acquisition by Non-U.S. Shareholders Cause U.S. firms to Pay Less Tax?" Journal of the American Taxation Association, Spring 2008, pp. 25-38. Harry Grubert, Debt and the Profitability of Foreign Controlled Domestic Corporations in the United States, Office of Tax Analysis Technical Working Paper No. 1, July 2008, http://www.ustreas.gov/offices/tax-policy/library/otapapers/otatech2008.shtml\#2008.

${ }^{59}$ In addition to the 2007 Treasury study cited above, see Jim A. Seida and William F. Wempe, "Effective Tax Rate Changes and Earnings Stripping Following Corporate Inversion," National Tax Journal, vol. 57, December 2007, pp. 805-828. They estimated $\$ 0.7$ billion of revenue loss from four firms that inverted. Inverted firms may, however, behave differently from foreign firms with U.S. subsidiaries.

${ }^{60}$ Harry Grubert, "Intangible Income, Intercompany Transactions, Income Shifting, and the Choice of Location," National Tax Journal, Vo. 56,March 2003, Part 2.

${ }^{61}$ Rosanne Altshuler and Harry Grubert, "Governments and Multinational Corporations in the Race to the Bottom," Tax Notes International, February 2006, pp. 459-474.
} 
high-tax countries; for example, Japan, Canada, and Germany accounted for $18 \%$ of the total. ${ }^{62}$ At the same time, about $14 \%$ of the estimate reflected transactions with countries that appear on tax haven lists: the Netherlands, Taiwan, Singapore, Hong Kong, and Ireland.

Some evidence that points to the importance of intangibles and the associated profits in tax haven countries can be developed by examining the sources of dividends repatriated during the "repatriation holiday" enacted in $2004 .{ }^{63}$ This provision allowed, for a temporary period, dividends to be repatriated with an $85 \%$ deduction, leading to a tax rate of $5.25 \%$. The pharmaceutical and medicine industry accounted for $\$ 99$ billion in repatriations or $32 \%$ of the total. The computer and electronic equipment industry accounted for $\$ 58$ billion or $18 \%$ of the total. Thus these two industries, which are high tech firms, accounted for half of the repatriations. The benefits were also highly concentrated in a few firms. According to a recent study, five firms (Pfizer, Merck, Hewlett-Packard, Johnson \& Johnson, and IBM) are responsible for $\$ 88$ billion, over a quarter (28\%) of total repatriations. ${ }^{64}$ The top ten firms (adding Schering-Plough, Du Pont, Bristol-Myers Squibb, Eli Lilly, and PepsiCo) accounted for 42\%. The top 15 (adding Procter and Gamble, Intel, Coca-Cola, Altria, and Motorola accounted for over half (52\%). These are firms that tend to, in most cases, have intangibles either in technology or brand names.

Finally, as shown in Table 5, which lists all countries accounting for at least $1 \%$ of the total of eligible dividends (and accounting for $87 \%$ of the total), most of the dividends were repatriated from countries that appear on tax haven lists.

Table 5. Source of Dividends from “Repatriation Holiday": Countries Accounting for at Least I\% of Dividends

\begin{tabular}{|c|c|}
\hline Country & Percentage of Total \\
\hline Netherlands & 28.8 \\
\hline Switzerland & 10.4 \\
\hline Bermuda & 10.2 \\
\hline Ireland & 8.2 \\
\hline Luxembourg & 7.5 \\
\hline Canada & 5.9 \\
\hline Cayman Islands & 5.9 \\
\hline United Kingdom & 5.1 \\
\hline Hong Kong & 1.7 \\
\hline Singapore & 1.7 \\
\hline Malaysia & 1.2 \\
\hline
\end{tabular}

Source: Internal Revenue Service

\footnotetext{
${ }^{62}$ Data are presented in “Who's Watching our Back Door?” Business Accents, Florida International University, Fall 2004, pp. 26-29.

${ }^{63}$ Data are taken from Melissa Redmiles, "The One-Time Dividends-Received Deduction," Internal Revenue Service Statistics of Income Bulletin, Spring 2008, http://www.irs.ustreas.gov/pub/irs-soi/08codivdeductbul.pdf.

${ }^{64}$ Rodney P. Mock and Andreas Simon, "Permanently Reinvested Earnings: Priceless," Tax Notes, November 17, 2008, pp. 835-848.
} 


\section{Methods of Avoidance and Evasion by Individuals}

Individual evasion of taxes may take different forms and they are all facilitated by the growing international financial globalization and ease of making transactions on the Internet. Individuals can purchase foreign investments directly (outside the United States), such as stocks and bonds, or put money in foreign bank accounts and simply not report the income (although it is subject to tax under U.S. tax law). There is little or no withholding information on individual taxpayers for this type of action. They can also use structures such as trusts or shell corporations to evade tax on investments, including investments made in the United States, which may take advantage of U.S. tax laws that exempt interest income and capital gains of non-residents from U.S. tax. Rather than using withholding or information collection the United States largely relies on the Qualified Intermediary (QI) program where beneficial owners are not revealed. To the extent any information gathering from other countries is done it is through bilateral information exchanges rather than multilateral information sharing. The European Union has developed a multilateral agreement but the United States does not participate.

\section{Tax Provisions Affecting the Treatment of Income by Individuals}

The ability of U.S. persons (whether firms or individuals) to avoid tax on U.S. source income that they would normally be subject to arises from U.S. rules that do not impose withholding taxes on many sources of income. In general interest and capital gains are not subject to withholding. Dividends, non-portfolio interest (such as interest payments by a U.S. subsidiary to its parent), capital gains connected with a trade or business, and certain rents are subject to tax, although treaty arrangements widely reduce or eliminate the tax on dividends. In addition, even when dividends are potentially subject to a withholding tax, new techniques have developed to transform, through derivatives, those assets into exempt interest. ${ }^{65}$

The elimination of tax on interest income was unilaterally initiated by the United States in 1984, and other countries began to follow suit. ${ }^{66}$ Currently, fears of capital flight are likely to keep countries from changing this treatment. However, it has been accompanied with a lack of information reporting and lack of information sharing that allows U.S. citizens, who are liable for these taxes, to avoid them whether on income invested abroad or income invested in the United States channeled through shell corporations and trusts. Citizens of foreign countries can also evade the tax, and the U.S. practice of not collecting information contributes to the problem.

Based on actual tax cases, Guttenberg and Avi-Yonah describe a typical way that U.S. individuals can easily evade tax on domestic income through a Cayman Islands operation using current technology with little expense with current technology. The individual, using the Internet, can open a bank account in the name of a Cayman corporation that can be set up for a minimal fee. Money can be electronically transferred without any reporting to tax authorities, and investments

\footnotetext{
${ }^{65}$ See Joint Committee on Taxation Tax Compliance and Enforcement Issues With Respect to Offshore Entities and Accounts, JCX-23-09, March 30, 2009, p. 6 for a discussion.

${ }^{66}$ This history is described by Reuven Avi-Yonah in testimony before the Committee on Select Revenue Measures of the Ways and Means Committee, March 5, 2008.
} 
can be made in the United States or abroad. Investments by non-residents in interest bearing assets and most capital gains are not subject to a withholding tax in the United States. ${ }^{67}$

In addition to corporations, foreign trusts can be used to accomplish the same approach. Trusts may involve a trust protector who is an intermediary between the grantor and the trustees, but whose purpose may actually be to carry out the desires of the grantor. Some taxpayers argue that these trusts are legal but in either case they can be used to protect income from taxes, including those invested in the United States, from tax, while retaining control over and use of the funds.

\section{Limited Information Reporting Between Jurisdictions}

In general, the international taxation of passive portfolio income by individuals is easily subject to evasion because there is no multilateral reporting of interest income. Even in those cases where bilateral information sharing treaties, referred to as Tax Information Exchange Agreements (TIEAs) are in place, they have limits. As pointed out by Avi-Yonah most of these agreements are restricted to criminal matters, which are a minor part of the revenues involved and pose difficult issues of evidence. Also, these agreements sometimes require that the activities related to the information being sought constitute crimes in both countries which can be a substantial hurdle in cases of tax evasion. The OECD has adopted a model agreement with the "dual criminality" requirements. ${ }^{68}$ TIEAs usually allow for information only upon request, requiring the United States and other countries to identify the potential tax evaders in advance and they do not override bank secrecy laws.

In some cases the countries themselves have little or no information of value. One article, for example, discussing the possibility of an information exchange agreement with the British Virgin Islands, a country with more than 400,000 registered corporations, where laws require no identification of shareholders or directors, and require no financial records, noted: "Even if the BVI signs an information exchange agreement, it is not clear what information could be exchanged." $" 69$

\section{U.S. Collection of Information on U.S. Income and Qualified Intermediaries}

Under the QI program the United States itself does not require U.S. financial institutions to identify the true beneficiaries of interest and exempt dividends. The IRS has set up a QI program in 2001, under which foreign banks that received payments certify the nationality of their depositors and reveal the identity of any U.S. citizens. ${ }^{70}$ However, although QIs are supposed to certify nationality, ${ }^{71}$ apparently some rely on self certification. ${ }^{72}$ They are also subject to audit.

\footnotetext{
${ }^{67}$ Joseph Guttentag and Reven Avi-Yonah, "Closing the International Tax Gap," in Max B. Sawicky, ed. Bridging the Tax Gap: Addressing the Crisis in Federal Tax Administration, Washington, D.C., Economic Policy Institute, 2005.

${ }^{68}$ Testimony of Reuven Avi-Yonah, Subcommittee on Select Revenue Measures, Ways and Means Committee, March 31, 2009.

69 "Brown Pushes U.K. Tax havens On OECD Standards" Tax Notes International, April 20, 2009, pp. 180-181.

${ }^{70}$ A very clear and brief explanation of the origin of the QI program and of the requirements can be found in Martin Sullivan, "Proposals to Fight Offshore Tax Evasion," Tax Notes, April 20, 2009, pp. 264-268.

${ }^{71}$ For additional discussion of the QI program, see Joint Committee on Taxation, Tax Compliance and Enforcement Issues With Respect to Offshore Entities and Accounts, JCX-23-09, March 30, 2009.
} 
However, UBS, the Swiss bank involved in a tax abuse scandal that helped clients set up offshore plans, was a QI, and that event has raised some questions about the QI program.

A non-qualified intermediary must disclose the identity of its customers to obtain the exemption for passive income such as interest and or the reduced rates arising from tax treaties, but there are also questions about the accuracy of disclosures.

\section{European Union Savings Directive}

The European Union, in its savings directive, has developed among their members an option of either information reporting or a withholding tax. The reporting or withholding option covers the member countries as well as some other countries. Three states, Austria, Belgium, and Luxembourg have elected the withholding tax. While this multilateral agreement aids these countries' tax administration, the United States is not a participant.

\section{Estimates of the Revenue Cost of Individual Tax Evasion}

A number of different approaches have been used to estimate corporate tax avoidance, however, all of these approaches rely on data reported on assets and income. For individual evasion, estimates are much more difficult because the initial basis of the estimate is the amount of assets held abroad whose income is not reported to the tax authorities. In addition to this estimate, the expected rate of return and tax rate are needed to estimate the revenue cost.

Guttentag and Avi-Yonah estimate a value of $\$ 50$ billion in individual tax evasion, based on an estimate of holdings by high net worth individuals invested outside the United States at $\$ 1.5$ trillion. ${ }^{73}$ Using a rate of return of $10 \%$ and a tax rate of approximately a third, they obtain an estimate of $\$ 50$ billion. They also summarize two other estimates in 2002 of $\$ 40$ billion for the international tax gap by the IRS and $\$ 70$ billion by an IRS consultant.

Dharmapala suggests that this cost is overestimated. ${ }^{74}$ To the extent that the earnings are interest, he argues that the $10 \%$ rate of return is too high, while if it is dividends and capital gains, the tax rate is too high. Using a tax rate of $15 \%$ (currently applicable to capital gains and dividends) would lead to about $\$ 23$ billion. In the case of equity investments, if a third of the return is in dividends and half of capital gains is never realized, the tax rate would be $10 \%$ or about $\$ 15$ billion assuming the 10\% return. During 2002 and beginning in 2011, however, the tax rate on capital gains and dividends is $20 \%$, indicating a loss of $\$ 20$ billion rather than $\$ 15$ billion. Dharmapala argues that $2 \%$ is a more reasonable rate for interest returns. Since investors can earn tax free returns in the neighborhood of $4 \%$ to $5 \%$ on domestic state and local bonds, that

\footnotetext{
(...continued)

${ }^{72}$ Martin A. Sullivan, "Proposals to Fight Offshore Tax Evasion,” Tax Notes, April 20, 2009.

${ }^{73}$ Joseph Guttentag and Reven Avi-Yonah, "Closing the International Tax Gap," in Max B. Sawicky, ed. Bridging the Tax Gap: Addressing the Crisis in Federal Tax Administration, Washington, D.C., Economic Policy Institute, 2005.

${ }^{74}$ Dhammika Dharmapala, "What Problems and Opportunities are Created by Tax Havens?" Oxford Review of Economic Policy Issues, Vo. 24, Winter 2008, pp. 661-679.
} 
argument is not persuasive. To yield a 5\% after-tax return at a $35 \%$ tax rates would require a pretax yield of about $7.7 \%$. The estimate would then be $\$ 40$ billion.

The Tax Justice Network has estimated a worldwide revenue loss for all countries of $\$ 255$ billion from individual tax evasion, basically using a $7.5 \%$ return and a $30 \%$ tax rate. ${ }^{75}$ These assumptions would be consistent with a $\$ 33$ billion loss for the United States using the $\$ 1.5$ trillion figure.

\section{Alternative Policy Options to Address Corporate Profit Shifting}

Because much of the corporate tax revenue loss arises from activities that either are legal or appear to be so, it is difficult to address these issues other than with changes in the tax law Outcomes would likely be better if there is international cooperation. Currently, the possibilities for international cooperation appear to play a bigger role in options for dealing with individual evasion than with corporate avoidance.

\section{Broad Changes to International Tax Rules}

The first set of provisions would introduce broad changes in international tax rules, and include significant restrictions in deferral or allocation of income and capital.

\section{Repeal Deferral}

One approach to mitigate the rewards of profit shifting is to repeal deferral, or to institute true worldwide taxation of foreign source income Firms would be subject to current tax on the income of their foreign subsidiaries, although they would continue to be able to take foreign tax credits. According to estimates cited above, this change currently would raise from $\$ 11$ to $\$ 14$ billion per year.

Many of the issues surrounding the repeal of deferral have focused on the real effects of repeal on the allocation of capital. Traditionally, economic analysis has suggested that eliminating deferral would increase economic efficiency, although recently some have argued that this gain would be offset by the loss of production of some efficient firms from high-tax countries. Some have also argued for retaining the current system or moving in the other direction to a territorial tax. These economic issues are discussed in detail in another CRS report. ${ }^{76}$

Repeal of deferral would largely eliminate the value of the planning techniques discussed in this report. There are concerns, however, that firms could avoid the effects of repeal by having their parent incorporate in other countries that continue to allow deferral. The most direct and beneficial to reducing firms' tax liabilities of these planning approaches, inversion, has been addressed by legislation in $2004 .^{77}$ Mergers would be another method to counter the

\footnotetext{
${ }^{75}$ Tax Justice Network, Tax Us If You Can, September, 2005.

${ }^{76}$ CRS Report RL34125, Mortality of Americans Age 65 and Older: 1980 to 2004, by Andrew R. Sommers.

${ }^{77}$ Firms with $80 \%$ continuity of ownership would be treated as U.S. firms and firms with at least $60 \%$ continuity of (continued...)
} 
implementation of deferral, although mergers involve real changes in organization that would not likely be undertaken to gain a small tax benefit. Another possibility is that more direct portfolio investment (i.e., buying shares of stock by individual investors) in foreign corporations will occur. There has been a significant growth in this direct investment, although the evidence suggests this investment has been due to portfolio diversification and not tax avoidance. ${ }^{78}$

\section{Targeted or Partial Elimination of Deferral}

More narrow proposals to address deferral and tax avoidance would tax income in tax havens currently, or tax some additional income of foreign subsidiaries. They include

- eliminating deferral for specified tax havens.

- eliminating deferral in countries with tax rates that are below the U.S. rate by a specified proportion.

- eliminating deferral for income on the production of goods that are in turn imported into the United States.

- eliminate deferral for income on the production of goods that are exported.

- requiring a minimum payout share.

Restricting current taxation to tax havens would likely address some of the problems associated with transfer pricing and leveraging, without ending deferral entirely. Defining a tax haven under those circumstances would be crucial. A bill introduced in the $110^{\text {th }}$ Congress, S. 396, which defined as a U.S. firm any U.S. subsidiary in a tax haven not engaged in an active business, had a list of countries that was the same as the original OECD tax haven list, except for the U.S. Virgin Islands. Some countries, such as Ireland, that are often considered tax havens, would not be subject to such provisions, leaving some scope for corporate tax avoidance. In addition, firms could shift some operations to other lower tax countries and increase the amount of foreign tax credits available, which would be a loss to U.S. revenue. Some concerns have also been expressed that listing specific tax haven countries would make cooperative approaches, such as tax information sharing treaties, more difficult.

An alternative, which would not require identifying particular countries, would be to restrict deferral based on a tax rate that is lower than the U.S. rate by a specified amounts. For example, the French, who generally have a territorial tax, tax income earned in jurisdictions with tax rates one-third lower than the French rate. For the United States, whose tax rate is similar to the French rate, this ratio would indicate a tax rate lower than $24 \%$.

Another proposal directed to "runaway" plans would eliminate deferral for investments abroad that produce exports into the United States. S. 1284, also in the $110^{\text {th }}$ Congress, would impose current taxation on such activities by expanding Subpart F income to include income attributable to imports into the United States of goods produced by foreign subsidiaries of U.S. firms. The

\footnotetext{
(...continued)

ownership would be subject to tax on the transfer of assets for the next ten years.

${ }^{78}$ See CRS Report RL34125, Mortality of Americans Age 65 and Older: 1980 to 2004, by Andrew R. Sommers, CRS Report RL34115, Reform of U.S. International Taxation: Alternatives, by Jane G. Gravelle. See also International Corporate Tax Reform Proposals: Issues and Proposals, Forthcoming, Florida Tax Review, by Jane G. Gravelle.
} 
main problem with this proposal is administering it, which would include tracing selling to a third party for resale.

A somewhat different and more restrictive proposal was made by Senator Kerry during the 2004 presidential campaign. He proposed to eliminate deferral except in the case where income is produced and sold in the controlled foreign corporation's (CFC's) jurisdiction. This approach would, like deferral in general, be likely to significantly restrict opportunities for artificial profit shifting, since most of the income in tax haven or low-tax jurisdictions do not arise from real activity; indeed, these jurisdictions are too small in many cases to provide a market. As with the previous proposal, however, the administration of such a plan would be difficult.

A final option that would not go as far as eliminating deferral altogether would be to require some minimum share to be paid out.

\section{Allocation of Deductions and Credits with Respect to Deferred Income/Restrictions on Cross Crediting}

A proposal that does not end deferral but makes the shifting of profits from high-tax countries less attractive is a provision to allocate deductions and credits, so as to deny those benefits until income is repatriated. This approach was included in a tax reform bill introduced by Chairman Rangel of the Ways and Means Committee in 2007 (H.R. 3970) and is included in the current proposals by President Obama. Under this proposal, a portion of certain overall deductions, such as interest or overhead, that reflects the share of foreign deferred income, would be disallowed. The foreign tax credit allocation rule would allow credits for the share of foreign taxes paid that is equal to the share of foreign source income repatriated. Disallowed deductions and credits would be carried forward. (President Obama's proposal does not allocate research and experimental expenses).

The allocation-of-deductions provision would decrease the tax benefits of sheltering income in low-tax jurisdictions and encourage repatriation of income relative to current law and presumably reduce profit shifting, as well as decreasing benefits of real investment abroad. The foreign tax credit allocation rule could have a variety of effects. It would make foreign investment abroad less attractive because it would increase the tax on income when eventually repatriated, it would discourage investment in low-tax jurisdictions that could no longer be sheltered by foreign tax credits, and it would discourage repatriation of earnings on existing activities because of the potential tax to be collected.

The allocation of credits accomplishes some of the restrictions on cross crediting that could also be achieved by increasing the number of baskets. As discussed below, one possible separate basket would be for active royalties. Another possibility would be to impose a per country limit with a separate basket for each country (and baskets within each for passive, active, etc. income).

\section{Formula Apportionment}

Another approach to addressing income shifting is through formula apportionment, which would be a major change in the international tax system. With formula apportionment, income would be allocated to different jurisdictions based on their shares of some combination of sales, assets, and employment. This approach is used by many states in the United States and by the Canadian provinces to allocate income. (In the past, a three factor apportionment was used, but some states 
have moved to a sales based system.) Studies have estimated a significant increase in taxes from adopting formula apportionment. Slemrod and Shackleford estimate a 38\% revenue increase from an equally weighted three factor system. ${ }^{79} \mathrm{~A}$ sales based formula has been proposed by Avi-Yonah and Clausing that they estimate would raise about $35 \%$ of additional corporate revenue, or $\$ 50$ billion annually over the 2001-2004 period. ${ }^{80}$

The ability of a formula apportionment system to address some of the problems of shifting income becomes problematic with intangible assets. ${ }^{81}$ If all capital were tangible capital, such as buildings and equipment, a formula apportionment system based on capital would at least lead to the same rate of return for tax purposes across high-tax and low-tax jurisdictions. Real distortions in the allocation of capital would remain, since capital would still flow to low-tax jurisdictions, but paper profits could not be shifted. An allocation system based on assets becomes more difficult when intangible assets are involved. It is probably as difficult to estimate the stock of intangible investment (given lack of information on the future pattern of profitability) as it is to allocate it under arms length pricing. In the case of an allocation based on sales, profits that might appropriately be associated with domestic income as they arise from domestic investment in $\mathrm{R} \& \mathrm{D}$ would be allocated abroad. Moreover, new avenues of tax planning, such as selling to an intermediary in a low-tax country for resale, would complicate the administration of such a plan. Whether the benefits are greater than the costs is in some dispute.

One problem is that if the Untied States adopted the system there could be double taxation of some income and no taxation of other income unless there were a multinational plan. The European Union has been considering a formula apportionment, based on property, gross receipts, number of employees and cost of employment. This proposal and the consequences for different countries are discussed by Devereux and Loretz. ${ }^{82}$ If the European Union adopted such a plan it would be easier for the United States to adopt a similar apportionment formula without as much risk of double or no taxation with respect to its major trading partners.

\section{Eliminate Check the Box, Hybrid Entities, and Hybrid Instruments; Foreign Tax Credit Splitting From Income}

A number of proposals have been made to eliminate check the box, and in general to adopt rules that would require that legal entities be characterized in a consistent manner by the United States and the country where the entity is established. This proposal has been made by McIntyre. ${ }^{83}$ In general rules to require that legal entities be characterized in a consistent manner by the United

\footnotetext{
${ }^{79}$ Douglas Shackelford and Joel Slemrod, "The Revenue Consequences of Using Formula apportionment to Calculate U.S. and Foreign Source Income: A Firm Level Analysis,” International Tax and Public Finance, vol. 5, no. 1, 1998, pp. 41-57.

${ }^{80}$ Kimberly A. Clausing and Reuven A. Avi-Yonah, Reforming Corporate Taxation in a Global Economy : A Proposal to Adopt Formulary Apportionment, Brookings Institution: The Hamilton Project, Discussion paper 2007-08, June 2007.

${ }^{81}$ These and other issues are discussed by Rosanne Altshuler and Harry Grubert, "Formula Apportionment: Is it Better than the Current System and Are There Better Alternatives?" Oxford University Centre for Business Taxation, Working paper 09/01.

${ }^{82}$ Michael P. Devereux and Simon Loretz, "The Effects of EU formula Apportionment on Corporate Tax Revenues," Fiscal Studies, Vol. 29, no. 1, pp. 1-33. http://www3.interscience.wiley.com/cgi-bin/fulltext/119399105/PDFSTART? CRETRY $=1 \&$ SRETRY $=0$

${ }^{83}$ Michael McIntyre, “A Program for International Tax Reform,” Tax Notes, February 23, 2009, pp. 1021-1026.
} 
States and by the country where established and that tax benefits that arise from inconsistent treatment of instruments be denied would address this particular class of provisions that undermine Subpart F and the matching of credits and deductions with income. President Obama's proposal includes a provision that disallows a subsidiary to treat a subsidiary chartered in another country as a disregarded entity. It also includes a provision to prevent foreign tax credits without the associated income, which can currently be accomplished with reverse hybrids.

\section{Narrower Provisions Affecting Multinational Profit Shifting}

A number of more narrow provisions could be considered that would be more focused on preventing abuses and have fewer consequences for the overall structure of international corporate taxation.

\section{Tighten Earnings Stripping Rules}

In the American Jobs Creation Act a further restriction on earnings stripping rules was considered as an alternative to the anti-inversion measure. These provisions were not enacted, but were to be studied in a Treasury report. The 2004 House proposal would have raised revenue by dropping the debt to asset share test and lowering the interest share standard to $25 \%$ for ordinary debt, $50 \%$ for guaranteed debt, and $30 \%$ overall. In general, further restrictions on earnings stripping could be considered to address shifting through debt for U.S. subsidiaries of foreign parents.

President Obama's plan includes dropping the asset test and lowering the interest share standard to $25 \%$ for inverted firms, with respect to related party non-guaranteed debt.

\section{Foreign Tax Credits: Source Royalties as Domestic Income for Purposes of the Foreign Tax Credit Limit, Or Create Separate Basket; Eliminate Title Passage Rule; Restrict Credits for Taxes Producing an Economic Benefit}

As noted above, one of the issues surrounding the cross-crediting of the foreign tax credit is the use of excess credits to shield royalties from U.S. tax on income that could be considered U.S. source income. Two options might be considered to address that issue: sourcing these royalties as domestic income for purposes of the credit or putting them into a separate foreign tax credit basket. ${ }^{84}$ The same issue applies to the provision that allows half of the income from exports to be allocated to the country in which the title passes. President Obama's proposal includes a provision to restrict the crediting of taxes that are in exchange for an economic benefit (such as payments that are the equivalent of royalties).

\footnotetext{
${ }^{84}$ Harry Grubert, "Tax Credits, Source Rules, Trade and electronic Commerce: Behavioral Margins and the Design of International Tax Systems," Tax Law Review, vol. 58, January 2005; also issued as a CESIFO Working Paper (No. 1366), December 2004.; Harry Grubert and Rosanne Altshuler, "Corporate Taxes in a World Economy: Reforming the Taxation of Cross-Border Income," in John W. Diamond and George Zodrow, eds., Fundamental Tax Reform: Issues, Choices and Implications, Cambridge, MIT Press, 2008.
} 


\section{Transfer pricing}

Michael McIntyre has suggested some other proposals to deal with transfer pricing, which include making transfer pricing penalties nearly automatic for taxpayers who have not kept contemporaneous records. He also suggests use of some type of formula apportionment plan as a default for transfer pricing for non-complying taxpayers so the IRS does not have to conduct a detailed transaction by transaction assessment for the court.

President Obama's proposals would address some of the transfer pricing issues associated with the transfer of intangibles, by clarifying that intangibles include workforce in place, goodwill, and going concern value and that they are valued at their highest and best use. The plan would allow the IRS Commissioner to aggregate intangibles if that leads to a more appropriate value.

These proposals would likely have small effects. Any significant solution to the transfer pricing problem, especially for intangibles, is difficult to entertain short of an elimination of deferral.

\section{Codify Economic Substance Doctrine}

A final proposal that does not focus specifically on international tax avoidance and evasion but is relevant to these issues is a codification of the economic substance doctrine. Firms that enter into tax savings arrangements that are found not to have economic substance can have their tax benefits disallowed by the courts under what has become known as the economic substance doctrine. The doctrine is sometimes interpreted differently by different courts and recent legislative proposals have sought to make the doctrine more uniform through statute. Generally these proposals would require a transaction to meet both an objective test (profit was made) and a subjective test (profit was intended). Penalties are also imposed. Supporters argue that the stricter test will not only reduce tax avoidance but also make treatment more consistent across the courts. Some tax attorneys are concerned that more specific rules might provide a roadmap to structuring arrangements that will pass the test. President Obama's budget proposals include a two-part statutory standard.

\section{Prevent Dividend Repatriation Through Reorganizations}

President Obama's plan would revise the rule on reorganizations when property as well as stock is received to treat distributions as dividends in the case of cross border transactions.

\section{Options to Address Individual Evasion}

Most of the options for addressing individual evasion involve more information reporting and additional enforcement. There are options that would involve fundamental changes in the law, such as shifting from a residence to a source basis for passive income. That is, the United States would tax this passive income earned in its borders, just as is the case for corporate and other active income. This change involves, however, many other economic and efficiency effects that are probably not desirable. The remainder of the proposals discussed here do not involve any fundamental changes in the tax itself, but rather focus on administration and enforcement.

The options discussed below are drawn from many sources, including academics and practitioners, organizations, and the Internal Revenue Service, and contained in legislative 
proposals; citations to these sources are provided at this point and legislative proposals are summarized in the next section. ${ }^{85}$

\section{Information Reporting}

Expanded information reporting can involve multilateral efforts, changes in the current bilateral treaties, or unilateral changes.

\section{Multilateral Information Sharing or Withholding; International Cooperation}

The option that appears likely to recover most of the revenues would be to join in the European Union Directive, which would require information reporting on all income paid to foreign entities by U.S. banks and other institutions. If the beneficial owner cannot be identified, withholding could be imposed (a refund would be allowed if evidence of reporting to the home country could be shown). This approach has been proposed by the Tax Justice Network, which also suggests expanding the treaty to other tax havens. If the European Union is receptive, it would benefit other countries by reporting income paid to foreign nationals and benefit the United States by achieving third party information reporting on foreign investments of U.S. citizens.

Avi-Yonah and Avi-Yonah and Guttentag have suggested that current Treasury policy is to focus on bilateral agreements to achieve information exchange, but that the United States should also focus on cooperation with the OECD and G-20 and other appropriate organizations to improve information and persuade tax havens to enter into exchanges based on the OECD model. Shay suggests this approach as well and particularly references electronic information exchange.

The Tax Justice Network has proposed that the United Nations develop a global tax cooperation standard, set up a panel to determine compliant states, and deny recognition to non-compliant jurisdictions. They have also suggested that the IMF and Word Bank country assessments address tax compliance.

\section{Expanding Bilateral Information Exchange}

A number of commentators have suggested an increase in the scope of bilateral information treaties to provide for regular and automatic exchanges of information. This would require the U.S. banks to increase their collection of information.

Avi-Yonah and Avid-Yonah and Guttentag suggest adopting the model OECD bilateral Tax Information Exchange Agreement (TIEA). This information exchange would relate to civil as well as criminal issues, it would not require suspicion of a crime other than tax evasion, and

\footnotetext{
${ }^{85}$ For discussions of various proposals listed see Tax Justice Network, "Ending the Offshore Secrecy System," March 2009, http://www.taxjustice.net/cms/upload/pdf/TJN_0903_Action_Plan_for_G-20.pdf ; testimony of Reuven AviYonah, Peter Blessing, Stephen Shay, and Douglas Shulman before the Subcommittee on Select Revenue Measures of the Ways and Means Committee, March 31, 2009; Martin Sullivan, "Proposals to Fight Offshore Tax Evasion," Tax Notes, part 1, April 20, 2009, pp. 264-268; part 2: April 27, 2009, pp. 371-373; part 3, May 4, 2009, pp. 516-520; Reuven Avi-Yonah, Testimony before the Committee on Select Revenue Measures of the Ways and Means Committee, March 5, 2008; Testimony of Jack A. Blum and, Testimony on the Cayman Islands and Offshore Tax Issues before the Senate finance Committee, July 24, 2008; Michael McIntyre, “A Program for International Tax Reform,” Tax Notes, February 23, 2009, pp. 1021-1026.
} 
would override tax haven bank secrecy laws. Non-tax havens could be induced to make such agreements to obtain information, and thus, such a change would require collection of information on interest payments by banks and financial institutions. Treasury has proposed only 16 countries, but Avi-Yonah and Guttenberg suggest no reason to restrict the provision in this way. Treasury could use existing authority not to exchange information that might be misused by non-democratic foreign governments.

Martin Sullivan suggests that automatic information exchange might be the only way to stop evasion, which would require renegotiating existing agreements and a major policy change. He notes that that the proposed Stop Tax Haven Abuse Act (S. 506, H.R. 1265) requires automatic information exchange for a country to stay off the tax haven list.

\section{Unilateral Approaches: Withholding/Refund Approach; Increased Information Reporting Requirements}

This step is one that the United States could undertake without multilateral or bilateral cooperation, namely imposing withholding taxes on interest income and other exempt income received from U.S. sources by foreign intermediaries and providing a refund upon proof that the beneficial recipient was eligible. Avi-Yonah suggests this change with the hope that it would be adopted multilaterally.

A variation of this approach would be to require disclosure of the names of customers including beneficial owners, with withholding imposed if disclosure was not forthcoming. Such a proposal has been made by Michael McIntyre.

President Obama's proposals would impose withholding requirements with a refund mechanism, but only on non-qualified intermediaries.

The proposed Stop Tax Haven Abuse Act would require banks and QIs to file 1099 information returns for U.S. owners, based on beneficial ownership, which they are already required to know under anti-money-laundering rules. Also, any financial institution that establishes a trust, corporation, or bank account in a tax haven country would be required to report it to the IRS. President Obama's proposals appear to contain similar provisions. President Obama's proposals also include provisions to require information reporting by U.S. financial intermediaries and qualified intermediaries on transfers of funds and by U.S. persons and qualified intermediaries on the formation or acquisition of a foreign entity.

The proposed Stop Tax Haven Abuse Act would also require reporting by U.S. shareholders and persons forming, sending or receiving assets from Passive Foreign Investment Corporations (PFICs).

\section{Other Measures That Might Improve Compliance}

\section{Incentives/Sanctions for Tax Havens}

Avi-Yonah and Avi-Yonah and Guttenberg suggest a carrot and stick approach to tax havens. They argue that little of the benefit of tax havens flows to their sometimes needy residents, but rather to the professionals providing banking and legal services, who often live elsewhere. They 
suggest transitional aid to move away from these offshore activities. For non-cooperating tax havens, they suggest the Treasury use its existing authority to deny benefits of the interest exemption. They suggest that tax havens cannot continue to exist unless the wealthy countries permit it, because funds are not productive in tax havens.

The proposed Stop Tax Haven Abuse Act would extend to tax enforcement the sanctions of the Patriot Act used to impose penalties for money laundering and terrorist financing. Sanctions vary in severity and range from increased reporting on transactions to prohibitions. Sullivan points out that the U.S. government has used the Patriot Act sparingly, however, and questions whether this change would be a credible threat.

Blessing suggests that sanctions should be multilateral rather than unilateral.

\section{Revise the and Strengthen the Qualified Intermediary (QI)Program}

Several proposals relating to the QI program, which were discussed by witnesses at a Ways and Means Committee hearing on March 31, 2009, were reported by Sullivan. Some of these provisions are also included in the proposed Stop Tax Haven Abuse Act. If enough effective revisions could be made in the QI program, a great deal of potential information about U.S. taxpayers' income would be obtained. These proposals include the following. QIs would be required to inquire about and independently verify the ownership of foreign corporations and similar entities, information that they already must acquire to deal with money laundering. QIs would also be required to report any non-U.S. income of U.S. taxpayers. QIs would be required to submit information electronically, and IRS would be given resources to handle and use this information. The current exemption from withholding rules for bearer bonds (where no registration occurs) would be eliminated. Another possible change is to require QIs to share information about foreign customers to U.S. treaty partners (although one witness warned that this might be too severe a requirement). Finally, external audits of QIs would be strengthened by requiring QIs to promptly notify the IRS of any material failure in oversight, improve the evaluation of risk of circumvention of U.S. taxes by U.S. persons, and require audit oversight by a U.S. auditor.

Blum emphasizes the problem of accepting a shell corporation as the beneficial owner, and says this loophole in the law should be closed. He also suggests that penalties for failure to enforce should include withholding of capital gains as well as interest and dividends.

McIntyre stresses that audits of the QIs should be done by firms that do not at the same time sell tax shelters. Avi-Yonah and Avi-Yonah and Guttentag also suggest that IRS should require U.S. payors to issue form 1099s when they know or have reason to suspect the beneficial owner is a U.S. citizen (rather than the W8-BEN which provides evidence of foreign status).

President Obama's proposals would revise the treatment of non-qualified intermediaries. As noted above, the proposal includes a withholding/refund mechanism for non-qualified intermediaries. It would require that QIs can qualify only if all of their affiliates are QIs and, as noted above, increase information reporting by QIs. 


\section{Placing the Burden of Proof on the Taxpayer}

An important part of the Stop Tax Haven Abuse proposal is to place the burden of proof in court on the taxpayer; this approach was also suggested by Blum. As noted above, there is also a shift in the burden of proof for accounts with non-qualified intermediaries for filing an FBAR (Foreign Bank and Financial Account Report).

President Obama's proposal would create a presumption that the funds in foreign accounts are large enough to require an FBAR which is required when amounts exceed $\$ 10,000$. It would treat failure to file for amounts in excess of $\$ 200,000$ as willful, which permits criminal penalties and larger civil penalties.

\section{Treat Shell Corporations as U.S. Firms}

The Stop Tax Haven Abuse Act includes a provision to treat any firm that is publicly traded or has assets over $\$ 50$ million as a U.S. corporation. This provision would include hedge funds but would not affect subsidiaries of multinational firms because decisions are made by the parent firm. Sullivan argues that such a provision would have a devastating effect on the U.S. hedge fund industry, where offshore firms generally attract tax exempt U.S. investors and foreigners who wish to avoid filing tax returns, as well as U.S. tax evaders, and that legislative relief for U.S. tax exempt investors (pension funds, university endowments) would be likely.

\section{Impose Restrictions on Foreign Trusts}

The proposed Stop Tax Haven Abuse Acts would impose further restrictions on foreign trusts, by providing that any powers held by trust protectors would be attributed to the trust grantor, providing that any U.S. person who benefits from the trust will be treated as a formal beneficiary even if not named, providing that a future or contingent beneficiary be treated as a current one, and treating loans of assets and property as distributions. The Senate Finance Committee draft would expand the definition of contributions to include items such as art and jewelry.

\section{Treat Dividend Equivalents as Dividends}

As noted earlier, the withholding tax on dividends has been avoided with the use of derivatives and other arrangements to re-characterize them as interest. The proposed Stop Tax Haven Abuse Act would treat dividend equivalents as dividends. Proposals for change in this area were also made by Avi-Yonah. President Obama's plan treats equity swaps as dividends.

\section{Extend the Statute of Limitations}

Extensions in the statute of limitations are said by some to be needed due to the complexity of the international cases and difficulty of obtaining information. Extension has been proposed by numerous commentators, is supported by the IRS officials and is included in the proposed Stop Tax Haven Abuse Act, proposals discussed by the Senate Finance Committee, and proposals made by President Obama. These legislative proposals would extend the statute of limitations from three years to six years, but Blum also suggests the possibility of ten years. 


\section{Greater Resources for the Internal Revenue Service to Focus on Offshore}

Numerous suggestions have been made to expand IRS resources for combating overseas tax abuses. President Obama's proposal, for example, has proposed to fund 800 new positions to combat international abuses.

Blum says that agents should not be pressured to give up difficult cases because of short-term performance goals based on closing cases and collecting revenues.

\section{Make Civil Cases Public as a Deterrent}

Blum suggests all settlements involving offshore schemes in excess of \$1 million should be excluded from the restrictions of Section 6103 that require settled civil cases to be confidential. He argues that no one knows about these cases and thus taxpayers think the possibility of being caught is small.

\section{Revise Rules for FBAR (Foreign Bank Account Report)}

Blum argues that language in the FBAR should be clarified to make it easier for the Justice Department to pursue cases; the proposed Stop Tax Haven Abuse Act would change the disclosure rules to make this information easier to use. The FBAR report on foreign bank accounts is filed separately from the tax return; individuals must check a box to indicate whether or not they have these accounts. It is possible that a reporting requirement on the tax return would increase the visibility and force of this requirement. The Senate Finance Committee would require this report to be filed with the tax return and require due diligence on the part of tax preparers to determine if it should be filed. (Note also, as discussed below, that some of the strengthened penalties relate to FBAR.) President Obama's plan would require the information from the FBAR to also be reported on the tax return and any transfer of funds that sums to more than $\$ 10,000$ would also be reported.

\section{Joe Doe Summons}

A provision in the proposed Stop Tax Haven Abuse Act would make it easier to issue John Doe summons where the IRS does not know the names of taxpayers and now must ask courts for permission to serve the summons. This section provides that in any case involving offshore secret accounts, the court is to presume tax compliance is at issue, to relieve the IRS of the obligation when the only records sought are U.S. bank records, and to issue John Doe summons for large investigative projects without addressing each set of summons separately.

\section{Strengthening of Penalties}

Increased penalties are included in the proposed Stop Tax Haven Abuse Act, the Finance Committee Draft and President Obama's proposals. Among the penalty provisions in various proposals are: increased penalties for failure to file FBARs; basing the FBAR penalty on the highest amount in period rather than on a particular day; and increased penalties on abusive tax shelters, failure to file information on foreign trusts, and certain offshore transactions. President Obama's proposals would double accuracy related penalties for foreign transactions and increase penalties for trusts and permit them to be imposed if the amount in the trust cannot be established. 
The proposed Stop Tax Haven Abuse Act also includes a provision that legal opinions that take the position that a transaction is more likely than not to prevail for tax purposes will no longer shield taxpayers from penalties.

S. 386, the Fraud Recovery and Investment Act. would introduce criminal penalties. Some tax attorneys have questioned whether these proposals are too harsh or might undermine amnesty or voluntary compliance. ${ }^{86}$

\section{Address Tax Shelters; Codify Economic Substance Doctrine}

The proposed Stop Tax Haven Abuse Act would make a number of additional changes addressing tax shelters, including prohibiting the patenting of tax shelters, developing an examination procedure so that bank regulators could detect questionable tax activities, disallowing fees contingent on tax savings, removing communication barriers between enforcement agencies, codifying regulations, making it clear that prohibition of disclosure by tax preparers does not prevent congressional subpoenas, and providing standards for tax shelter opinion letters.

It would also codify the economic substance doctrine. This proposal is discussed among options for reducing corporate tax avoidance, but would also be applicable to individual evasion issues.

\section{Regulate the Rules Used by States to Permit Incorporation}

Blum suggests that all U.S. Limited Liability Companies (LLCs) have a taxpayer ID number, a requirement not imposed in Delaware and other states that keep no records of ownership. S. 569 would tighten regulations to require record-keeping and identification of beneficial owners of corporations and LLCs and commission a study of partnerships and trusts.

\section{Make Suspicious Activity Reports Available to Civil Side of IRS}

The proposal that information on suspicious activity reports filed by financial institutions under anti-money laundering acts be made available to the civil side of IRS was made by Blum, who indicated that agency policy at the top levels had prohibited this information sharing. It is included in a provision in the Stop Tax Haven Abuse Act.

\section{Summary of Legislative Proposals}

This section summarizes current legislative proposals that are designed to address or have consequences for international tax evasion and avoidance.

\footnotetext{
${ }^{86}$ See Jeremiah Coder, "Proposed offshore Crime Legislation Worries Defense Bar," Tax Notes Today, March 23, 2009. The attorneys are concerned that money laundering charges would not have to be approved through the Department of Justice's tax division, that penalties of up to 20 years gives prosecutors too much power, that the provisions may trap taxpayers who want to participate in IRS voluntary disclosure, and that they would also discourage the "quiet disclosure" where taxpayers simply report past information.
} 


\section{President Obama's International Tax Proposals ${ }^{87}$}

President Obama's international proposals include several proposals that relate to multinational corporations: allocation of deductions and credits, a restriction on use of foreign tax credits when associated income is not recognized, and a restriction on check-the-box. They also include proposals addressing individual tax evasion. Overall these provisions are projected to raise $\$ 210$ billion for FY2010-2019. The provisions are discussed in the order in which they are presented unless otherwise noted, since revenue effects depend on that order. Note also that the budget proposes additional resources for the IRS for international enforcement.

\section{Provisions Affecting Multinational Corporations and Other Tax Law Changes}

\section{Hybrid Entities and Check-the Box}

The most significant provision based on revenue gain is a revision directed at hybrid entities and check-the-box. This provision requires that a corporation cannot disregard a subsidiary corporation unless it is incorporated in the same jurisdiction. This rule does not apply to the parent and its first level subsidiary. Thus, a U.S. parent with a subsidiary in Ireland could treat that subsidiary as a branch (disregard it as a separate entity). The Irish subsidiary, however, could not treat its German subsidiary as a disregarded entity. This provision is projected to raise $\$ 86.5$ billion for FY2010-FY2019. ${ }^{88}$

\section{Allocation of Deductions and Credits}

Two of these proposals would allocate deductions and credits, so as to deny those benefits until income is repatriated. This approach was included in a tax reform bill introduced by Chairman Rangel of the Ways and Means Committee in 2007 (H.R. 3970). A portion of overall deductions, such as interest, that reflects the share of foreign deferred income, would be disallowed until the income is repatriated. The foreign tax credit allocation rule would allow credits for the share of foreign taxes paid that is equal to the share of foreign source income repatriated, a provision the discussion of the proposals refers to as pooling. Disallowed deductions and credits would be carried forward. The proposal specifically excludes deductions for research and experimentation from the allocation rule.

The revenue gain for FY2010-2019 is \$60.1 billion for the deduction allocation and \$24.5 billion for the foreign tax credit pooling.

\footnotetext{
${ }^{87}$ A summary was posted at http://www.whitehouse.gov/the_press_office/LEVELING-THE-PLAYING-FIELDCURBING-TAX-HAVENS-AND-REMOVING-TAX-INCENTIVES-FOR-SHIFTING-JOBS-OVERSEAS/.

${ }^{88}$ A discussion of these provisions and revenue estimates can be found in the Treasury's Green Book, General Explanations of the Administration's Fiscal Year 2010 Revenue Proposals, http://www.treas.gov/offices/tax-policy/ library/grnbk09.pdf.
} 


\section{Limiting the Foreign Tax Credit; Reverse Hybrids}

Another provision aimed at multinational corporations would disallow foreign tax credits when the associated income is not received, as can occur with reverse hybrids. A matching rule would apply. This provision is estimated to raise \$18.5 billion in revenue for FY2010-FY2019.

\section{Transfer Pricing of Intangibles}

The proposal would clarify several rules that are relevant to the transfer of intangibles. First, it would clarify that intangibles include workforce in place, goodwill, and going concern value. Second, it would allow the IRS commission to aggregate intangibles if that leads to a more appropriate value. Finally, it would clarify that intangibles are to valued at their highest and best as it would be by a willing buyer and seller with reasonable knowledge of the relevant facts. This provision is projected to raise \$2.9 billion for FY2010-FY2019.

\section{Earnings Stripping by Inverted Firms}

The proposal would apply the provisions on earnings stripping discussed in 2004 to inverted firms. For these firms the debt-to-equity safe harbor would be eliminated and non-guaranteed related party debt would not be deductible when debt exceeded the $25 \%$ threshold. This provision is projected to raise $\$ 1.2$ billion for FY2010-FY2019.

\section{Prevent Repatriation of Earnings in Cross Border Transactions}

The plan includes a proposal to require that distributions that are characterized as reorganizations but are in the nature of a dividend repatriation are subject to tax. This issue arises within the framework of an exchange of stock on the one hand for stock and property (called "boot") and rules that provide the minimum of gain be based on the boot or overall gain. This proposal is projected to raise $\$ 297$ million from FY2010 to FY2019.

\section{Repeal 80/20 Rules}

This provision is related to dividends and affects individuals. Under current law, withholding is applied to interest and dividends paid by corporations, but there is an exception for firms who have $80 \%$ of their income from active foreign operations. This provision would repeal that exception, raising projected revenues of \$1.2 billion for FY2010-FY2019.

\section{Treat Equity Swaps as Dividends}

This provision addresses the problem of disguising dividends that are subject to taxation as interest that is not. This provision, which would generally treat equity swaps as dividends, would raise \$1.4 billion for FY2010-FY2019.

\section{Foreign Tax Credits for Dual Capacity Taxpayers}

This provision would disallow a foreign tax credit for taxes paid where there is an income tax that is paid in part to receive a benefit (i.e., the firm is paying a tax in a dual capacity) unless the income tax is generally imposed on the country's own residents as well as foreign persons. The 
current rule does not require the tax to be imposed on the country's residents. This provision typically relates to taxes being substituted for royalties in oil producing countries; there is a provision that it will not abrogate any existing treaties. This provision is projected to raise $\$ 4.5$ billion for FY2010-FY2019.

\section{Economic Substance Doctrine}

Although not included with the international proposals, the proposal includes a codification of the economic substance doctrine, that requires both a subjective (profit intended) and objective (profit achieved) test.

\section{Provision Relating to Individual Tax Evasion}

The President's proposal includes a number of provisions relating to individual evasion including reporting of information, withholding and various penalties. Overall these provisions are projected to raise revenues of $\$ 8.7$ billion from FY2010 to FY2019.

\section{Qualified Intermediaries}

Qualified Intermediaries would be required to identify all account holders that are U.S. persons and file 1099s information forms relative to them. All related firms of a QI would be required to be QIs. QIs would also have to report on the transfer of funds and the forming or acquisition of foreign entities (along with U.S. third party reporting discussed below).

\section{Nonqualified Intermediaries}

Nonqualified intermediaries would be required to withhold $30 \%$ on periodic payments (these payments are termed FDAP for fixed or determinable annual or periodic payments) and $20 \%$ on gross gains from sale; exempt taxpayers would have to apply for refunds. Some exceptions are allowed.

\section{Other Increased Third Party Reporting}

U.S. financial intermediaries and qualified intermediaries would be required to report financial transfers. U.S. person and qualified intermediaries would be required to report the formation or establishment of a foreign entity.

\section{Additional Information Reported on Tax Returns}

Individuals who are required to file an FBAR (Foreign Bank and Financial Account Reports) would also be required to report $t$ his information on the tax return. They would also be required to report any transfer of funds to a foreign entity, unless they are less than $\$ 10,000$.

\section{Burden of Proof and Presumption Provisions}

The proposal contains a number of provisions that provide evidentiary presumptions (shifts in the burden of proof). If an individual has a foreign account it is presumed to be large enough to 
require filing an FBAR. If a person has an account of over $\$ 200,000$ it is presumed that failure to file is willful (which opens the possibility of criminal as well as higher civil penalties). If a payment subject to withholding is made to a foreign person on an FDAP, the presumption is that that person is not eligible for withholding.

\section{Statute of Limitations}

The statute of limitations for cross border transactions is extended from three to six years.

\section{Penalties}

The $20 \%$ accuracy related penalty that already applies would be increased to $40 \%$ for transactions involving foreign accounts where the taxpayer failed to disclose reportable information. A reasonable cause exception would not be available. In the case of failure to report or underreporting foreign trusts, the initial penalty is $35 \%$ of the trust amount. If the failure to report continues for ninety days an additional penalty of $\$ 10,000$ is imposed for each 30 -day period, but the total cannot exceed the amount of the trust. This provision would change the initial penalty from $35 \%$ of the trust amount to the greater of $35 \%$ or $\$ 10,000$. The $\$ 10,000$ for each 30 -day period would be continued indefinitely, with a refund of any excess when the taxpayer does report. This proposal addresses the problem of the IRS not being able to assess a penalty because it cannot determine the amount in the account.

\section{Stop Tax Haven Abuse Act, S. 506 and H.R. $1265^{89}$}

This bill has been introduced in the Senate by Senator Carl Levin and in the House by Representative Lloyd Doggett.

Section 101 would provide a burden of proof change. It would require the taxpayer involved in offshore secrecy jurisdictions to produce evidence, based on the presumption that the taxpayer is in control, that funds or other property are not taxable income, and that the account is not large enough to trigger a reporting threshold. (The bill also addresses securities law issues.) This section also contains the list of 34 tax haven jurisdictions taken from IRS court filings, and provides Treasury with the authority to add or remove jurisdictions. An important standard for being excluded from the list is an effective, and automatic, exchange of information.

Section 102 would expand the provisions in the Patriot Act of 2001, which gave Treasury the authority to require domestic financial institutions to take special measures (including providing information and prohibiting transactions) with respect to foreign jurisdictions relating to money laundering to cover instances of impeding U.S. tax enforcement.

Section 103 would require a publicly traded corporation or one with gross assets of $\$ 50$ million or more whose management and control occurs primarily in the United States to be treated as a U.S. company. This provision is directed at shell corporations, including hedge funds and investment management businesses, set up in jurisdictions such as the Cayman Islands. It would not apply to

\footnotetext{
${ }^{89}$ For a more detailed explanation of the bill see Senator Levin's Introductory Remarks, March 3, 2009. This proposal has also been discussed by Martin Sullivan, "Proposals to Fight Offshore Tax Evasion, Part 3," Tax Notes, May 4, 2009, pp. 516-520.
} 
subsidiaries of U.S. corporations simply because some decisions are made at the parent headquarters, but would still apply to shell subsidiaries.

Section 104 would extend the limit on audit periods from three years to six years for offshore jurisdictions with secrecy laws.

Section105 would require U.S. financial institutions and brokers to file 1099 forms for any foreign account when they know the beneficial owner is a U.S. person. It would also require these institutions to report to the IRS when they set up offshore accounts and entities.

Section 106 addresses potential trust abuses. Foreign trusts have employed liaisons called trust protectors as a way for shielding U.S. taxpayers exercising control over the trust; the legislation provides that any powers held by a trust protector would be attributed to the trust grantor. It also provides that any U.S. person benefitting from a trust is treated as a beneficiary even if not named in the trust instrument, that future or contingent beneficiaries are treated as current ones, and that loans of assets and property as well as cash or security are treated as trust distributions.

Section 107 addresses legal opinions, stating that an activity is more likely than not to survive challenge by the IRS, which are used to shield taxpayers from large penalties. The legislation provides that a legal opinion of this nature would not apply in an offshore secrecy jurisdiction, providing exceptions to protect legitimate operations.

Section 108 would prevent dividend equivalents from escaping the dividend withholding tax.

Section 109 addresses reporting by passive foreign investment corporations (PFICs) by codifying proposed regulations regarding PFIC reporting by direct or indirect shareholders who are U.S. persons, and also requiring reporting by U.S. persons who directly or indirectly cause the PFIC to be formed or sent or receive assets.

Some of the sections of title II of the bill affect securities law rather than tax issues. Some provisions are tax-related, however.

Section 204 addresses an IRS John Doe summons where the IRS does not know the names of taxpayers and now must ask courts for permission to serve the summons. This section provides that in any case involving offshore secret accounts, the court is to presume tax compliance is at issue, to relieve the IRS of the obligation when the only records sought are U.S. bank records, and to allow them to issue John Doe summonses for large investigative projects without addressing each set of summonses separately.

Section 205 would address issues relating to the Foreign Bank and Financial Account Report (FBAR) requirement for a person controlling a foreign financial account of over $\$ 10,000$. This is a additional rule from the requirement to report this information on the tax return, and IRS is now charged with enforcing this FBAR requirement. This provision would amend tax disclosure rules to more easily permit IRS to use tax data., change the penalty to refer to the highest average in the account during a year (and not on a specific day), and allow IRS access to information on Suspicious Activity Reports (SAR).

The last title of the bill relates to abusive tax shelters, and contains several provisions. It would strengthen penalties, prohibit the patenting of tax shelters, require development of an examination procedure so that bank regulators could detect questionable tax activities, disallow fees contingent on tax savings for tax shelters, remove communication barriers between enforcement 
agencies, codify regulations and make it clear that prohibition of disclosure by tax preparers does not prevent congressional subpoenas, and provide standards for tax shelter opinion letters. It would also codify the economic substance doctrine, to require both an objective and subjective test for economic substance.

\section{Finance Committee Proposal}

A draft of this proposal was circulated on March 12 and has been discussed by Sullivan. ${ }^{90}$

- It would require entities transferring funds offshore to report to the IRS the amount, destination, and account information. Publicly traded companies would be excluded.

- The statute of limitations would be extended from three to six years for tax returns that report or should have reported certain international transactions.

- It would require the foreign bank and financial account report (FBAR) to be filed with the tax returns.

- Tax preparers would be required to ask due diligence questions to determine whether an FBAR should be filed.

- The foreign trust failure-to-file penalty would be increased to a $\$ 10,000$ minimum and the definition of property considered to be a distribution for foreign trusts would be expanded, and would include artwork and jewelry.

- Fines and penalties on payments attributable to certain offshore transactions would be doubled.

- A provision in the Heroes Earnings Assistance and Relief Tax Act of 2008 (P.L. 110-245) would be modified to require offshore entities that hire workers under a government contract be treated as American employers by establishing a rule that any individual who performs at least 100 hours of service a month is an employee and not an independent contractor.

\section{Fraud Enforcement and Recovery Act, S. 386}

This proposal, introduced by the Chairman Leahy of the Senate Judiciary Committee, includes a provision to apply the international money laundering statute to tax evasion, and set aside funds for the Justice Department to pursue financial fraud, including funds to the tax division. It has been passed by the Senate. The House version of the bill, H.R. 1748, does not include the tax provision but does include additional funds.

\footnotetext{
${ }^{90}$ See Committee on Finance News Release, March 12, 2009, http://finance.senate.gov/press/Bpress/2009press/ prb031209b.pdf; See also Martin A. Sullivan, "Proposals to fight Offshore Tax Evasion, Part 2," Tax Notes, April 27, 2009, pp. 371-373.
} 


\section{Incorporation Transparency and Law Enforcement Assistance Act,}

\section{S. 569}

This proposal would establish uniform requirements for states relating to the disclosure of beneficial owners of corporations and limited liability companies, including updating and maintenance of information after terminating, imposing additional requirements for those not U.S. citizens or permanent residents, providing penalties, and updating of such disclosures. It also authorizes a study of requirements of partnerships, trusts, and other legal entities. This bill is relevant, among other things, to issues raised about the use of states as international tax havens.

\section{Author Contact Information}

Jane G. Gravelle

Senior Specialist in Economic Policy

jgravelle@crs.loc.gov, 7-7829 